NBER WORKING PAPER SERIES

\title{
THE QUIET REVOLUTION THAT TRANSFORMED WOMEN'S EMPLOYMENT, EDUCATION, AND FAMILY
}

\author{
Claudia Goldin \\ Working Paper 11953 \\ http://www.nber.org/papers/w11953 \\ NATIONAL BUREAU OF ECONOMIC RESEARCH \\ 1050 Massachusetts Avenue \\ Cambridge, MA 02138 \\ January 2006
}

The 2006 Ely Lecture, delivered on January 6 at the American Economic Association Meetings Boston MA, was derived from this paper. I am grateful to Lawrence F. Katz for an embarrassingly large amount of guidance. I am indebted to the Andrew W. Mellon Foundation for providing access to the College and Beyond data set and for research funds provided to the Radcliffe Institute for Advanced Study where I am Katherine Hampson Bessell Fellow for 2005/2006. Claudia Olivetti and Bruce Weinberg were enormously generous in their data help and advice. Lisa Blau Kahn was instrumental in her assistance in using various data sets, and Crystal Yang provided able assistance on many details. First and foremost, I thank George Akerlof for inviting me to present the Ely Lecture. The views expressed herein are those of the author(s) and do not necessarily reflect the views of the National Bureau of Economic Research.

(C2006 by Claudia Goldin. All rights reserved. Short sections of text, not to exceed two paragraphs, may be quoted without explicit permission provided that full credit, including (C) notice, is given to the source. 
The Quiet Revolution that Transformed Women's Employment, Education, and Family Claudia Goldin

NBER Working Paper No. 11953

January 2006

JEL No. J1, J2, N3

\begin{abstract}
The modern economic role of women emerged in four phases. The first three were evolutionary; the last was revolutionary. Phase I occurred from the late nineteenth century to the 1920s; Phase II was from 1930 to 1950; Phase III extended from 1950 to the late 1970s; and Phase IV, the "quiet revolution," began in the late 1970s and is still ongoing. Three aspects of women's choices distinguish the evolutionary from the revolutionary phases: horizon, identity, and decision-making. The evolutionary phases are apparent in time-series data on labor force participation. The revolutionary phase is discernible using time-series evidence on women's more predictable attachment to the workplace, greater identity with career, and better ability to make joint decisions with their spouses. Each of these series has a sharp break or inflection point signifying social and economic change. These changes, moreover, coincide by birth cohort or period. The relationship between the development of modern labor economics and the reality of women's changing economic role is explored. The paper concludes by assessing whether the revolution has stalled or is being reversed. Women who graduated college in the early 1980s did not "opt-out,"but recent cohorts are too young to evaluate.

Claudia Goldin Department of Economics Harvard University Cambridge, MA 02138 and NBER cgoldin@harvard.edu
\end{abstract}




\section{Evolutionary and Revolutionary Phases}

Women's increased involvement in the economy was the most significant change in labor markets during the past century. Their modern economic role emerged in the U.S. in four distinct phases. The first three were evolutionary; the last was revolutionary. The revolution was a "quiet" one, not the "big-bang" type. The evolutionary phases led, slowly, to the revolutionary phase. I will first discuss the three evolutionary phases and how they led to the revolutionary phase. I will then describe the changes that occurred during the revolutionary phase, and end with whether the revolution, as some have claimed, is stalled or being reversed.

I am not using the terms "evolution" and "revolution" lightly. By the term evolution and the shift to revolution I mean something quite specific. The distinction between the two pertains to three aspects of women's choices and decisions. The first concerns "horizon." That is, whether at the time of human capital investment a woman perceives that her lifetime labor force involvement will be long and continuous or intermittent and brief. The second concerns "identity." That is, whether a woman finds individuality in her job, occupation, profession, or career. The third concerns "decision making." Here the distinction is whether labor force decisions are made fully jointly, if a woman is married or in a long term relationship, or, on the other hand, whether the woman is a "secondary worker" who optimizes her time allocation by taking her husband's labor market decisions as given to her.

Thus the transition from evolution to revolution was a change from static decisionmaking, with limited or intermittent horizons, to dynamic decision making, with long-term horizons. It was a change from agents who work because they and their families "need the money" to those who are employed, at least in part, because occupation and employment define

\footnotetext{
${ }^{1}$ George A. Akerlof and Rachel E. Kranton (2000) consider how individuals' conception of their identity affects their social interactions.
} 
one's fundamental identity and societal worth. It involved a change from "jobs" to "careers," where the distinction between these two concepts concerns both horizon and human capital investment. ${ }^{2}$ Those in the evolutionary phases married early enough that their adult identity was formed after marriage, whereas those in the revolutionary phase married late enough that their identity formation could precede marriage. It was a change from passive actors, who take the income and time allocation of other members as given, to active participants who bargain somewhat effectively in the household and the labor market.

The shift from evolution to revolution, moreover, did not occur only to more highly educated women although they will be a focus of this essay. Rather, the changes were far more universal, as can be seen in data on the age at first marriage, divorce, number and timing of children, relative earnings, and labor market attachment.

A chronology of the evolutionary phases is needed to understand the forces that led each to morph into the other and ultimately to the revolutionary phase. Some change occurs to cohorts and some is by period. Because working women range in age, typically from their late teens to their sixties, these precise dates should be considered with respect to women in their thirties. The chronology may be a bit different if another age group is chosen.

Phase I occurred from the late nineteenth century to the 1920s; Phase II, a transition era, was from about 1930 to 1950; and Phase III, the "roots of the revolution," took place from 1950 to around the mid- to late-1970s. I date Phase IV, the quiet revolution, as beginning in the late-

\footnotetext{
${ }^{2}$ The distinction used here between "job" and "career" concerns the degree to which the individual believes she will be in the labor force for a sufficient time to engage in substantial human capital investment both in formal schooling and on-the-job training. Those whose participation will be intermittent will take positions that involve less depreciation during work absences, whereas those with a long time horizon of employment will take positions that require more formal education, involve more internal promotion, and have a greater loss from out-of-work spells. These notions are similar to those in Jacob Mincer and Solomon Polachek (1974) and are consistent with the dictionary definition of "career" (e.g., "in mod. language [after Fr. carrière] freq. used for: A course of professional life or employment, which affords opportunity for progress or advancement in the world" Oxford English Dictionary).
} 
1970s, when the birth cohorts of the late 1940s were in their early thirties, and continuing to the present, for the revolution is not over.

What economic and social indicators reveal the outcomes of the phases? The primary series used to demonstrate economic and social change is labor force participation as well as the related series on annual hours of work and full-time work. But these series, I will show, reveal more about the evolutionary phases rather than the revolutionary phase. One must seek other series for evidence of the revolutionary phase.

The series on labor force participation, full-time work, and annual hours of work are fairly continuous, albeit with some periods of quickening. Although they do not reveal sharp changes, the increase in participation and the greater number of hours worked by women was a critical prerequisite for the transition from the evolutionary to the revolutionary phase. More important, though, is that labor force participation by itself is not revolutionary in the sense that I am using the word. Increased participation and greater hours of work need not involve changes in horizon, identity, and decision-making. Women in poor countries, for example, are often employed in the paid labor force to a considerable degree but few would claim they were part of a societal and economic revolution. Adult women were employed in the United States historically. Yet prior to the 1940s employed married women came disproportionately from the lower part of the education distribution. Their identities, just like that of women in poor countries, were not found in their occupations. Their decisions were made as secondary workers and their market work effort evaporated when family incomes rose sufficiently. ${ }^{3}$

The various series that disclose the revolutionary phase are wide ranging. They include the expectations of future employment by teenaged girls, the determinants of life satisfaction,

\footnotetext{
${ }^{3}$ On the U-shaped relationship between economic development and female labor force participation see Goldin (1995).
} 
various investments in human capital (such as college enrollment and graduation, college majors, enrollment and graduation from professional and graduate schools), earnings relative to comparable men, labor force participation of women with infants, lifetime labor force participation, the age at first marriage, and the fraction of one's life spent married. Each of these series contains a sharp break or inflection point signifying social change. These inflection points, moreover, are remarkably coincident in the approximately ten series I will present.

The revolutionary part of the process - like many revolutions - was preceded by fundamental, long-run, and evolutionary changes that were necessary but not sufficient for the revolutionary phase. Before I get to the revolutionary phase, I must first explore the three evolutionary phases, convince you that there was evolutionary and then revolutionary change, and account for the changes. I will, in addition, link the evolutionary changes to pioneering contributions to the subject of labor economics, mainly labor supply. I will then turn to the revolutionary period and address whether an authentic, long-lasting revolution occurred or whether the revolution has stalled or reversed. Although much that I have to say is well known and widely accepted, I promise to provide newly uncovered facts and interpretations.

\section{The Three Phases of Evolutionary Change and the Birth of Modern Labor Economics}

The evolutionary period, as I have noted, occurred in three phases. The shifts from one phase to the next were due to various exogenous changes. These changes include the increased relative demand for female office workers in the early twentieth century that made "nice" jobs available and the growth of educational institutions at the secondary level from the 1910s to the 1940s that greatly increased the supply of potential office workers. Changes in household production technology from the 1920s to the 1940s also altered female labor supply as did 
institutional changes that made part-time work readily available and dispensed with barriers to the employment of married women.

Each of the phases produced different magnitudes for the two key parameters of labor supply: the own-wage (compensated) elasticity and the income elasticity of the Slutsky equation. When considerable social stigma existed concerning the paid work of wives, the income effect was large (and negative). When, at the same time, the substitution effect was small, increased demand could do little to increase women's paid employment and higher incomes for husbands operated in the opposite direction. Thus, the growth of married women's employment had to await various changes that altered the two parameters of the Slutsky equation. For various reasons that will become clear, the substitution elasticity of labor supply eventually grew and the income effect (in absolute value) shrank. In the late 1940s and 1950s labor demand began to shift out across a rather elastic female labor supply function. The effect continued and married women's labor force participation rates climbed. Because the elasticities changed in each of the phases, so did the relative importance of labor supply and labor demand in explaining the increase in labor force participation and hours worked.

Each evolutionary phase, moreover, led to major advances in the field of modern empirical and theoretical labor economics that mirrored the reality of women's changing role. The study of labor was once mired in the institutions of the labor market. As women's employment expanded, economists began to study labor supply and the decisions made by families and households. My discussion of the evolution of modern labor economics will stop with developments in the 1960s as the field was firmly established by then and the list of economists who made major contributions since the 1960s is too large to include here.

Women's labor market choices and decisions have become central to the field of labor 
economics, as a perusal of any undergraduate text will demonstrate. ${ }^{4}$ It would not be much of an exaggeration to claim that women gave "birth" to modern labor economics, especially labor supply. Economists need variance to analyze changes in behavioral responses and women provided an abundance of that. Men, by and large, were not as interesting since their participation and hours varied far less in cross section and over time.

A. Phase I: Late nineteenth century to the 1920s-The Independent Female Worker From the late nineteenth century to the 1920 s female workers in the labor market, as opposed to those working in the household or family business, were generally young and unmarried. They were often piece workers in manufacturing or labored in the service sector as domestics and laundresses. These women experienced little or no learning on the job and saw only slight gain from formal human capital beyond common or elementary school, if that. ${ }^{5} \mathrm{~A}$ scant minority were professional workers, often teachers, and clerical employees, a group that expanded enormously beginning in the 1910s. The vast majority of women workers were poorly educated, often from low-income households and those headed by a foreign-born individual. During this phase the average married woman worker was less educated than the population average, suggesting that the income effect greatly swamped the substitution effect.

Prior to the 1920s women almost always exited the workforce at marriage although some in poorer homes and among the more highly educated did not. Substantial social stigma regarding the work of wives outside the home existed due in large measure to the nature of the

\footnotetext{
${ }^{4}$ See the undergraduate textbook by Ronald G. Ehrenberg and Robert S. Smith (2006) on the relative importance of research on women's labor force participation, hours, earnings, occupations, household production, human capital investment, and so forth. The index listing for "women" is more than three times longer than that for "men," and there are additional listings under "gender," "discrimination," "maternity benefits," and others relating directly to women.

${ }^{5}$ About 47 percent of all female workers in manufacturing in 1890 were paid by the piece and more than 30 percent of all white female workers in 1890 were in the service sector. In two surveys of working women in 1907 in which formal education was asked the return to a year of education was between 1 and 2 percent estimated around six years of education (Goldin 1990, table 4.1).
} 
work. Jobs were often dirty, dangerous, repetitive, and long in hours per day and days per week.

The income elasticity was therefore large whereas the substitution elasticity was small, although its precise magnitude is uncertain. The end result was that the (negative) income effect from increased husbands' income greatly exceeded the (positive) substitution effect from increased wives' earnings. ${ }^{6}$

With a very inelastic labor supply function, the increase in female labor force participation rates from 1890 to 1930 -9.5 percentage points for women 25 to 44 years and 7.3 for married women 35 to 44 years (Figure 1) — must have resulted largely from shifts in the labor supply function. In addition, the large negative income effect means that positive supply shifts had to have been substantial in magnitude to outweigh the negative effect of increased husbands' income. ${ }^{7}$

The field of modern labor economics, like that of market work for married women, was nascent at the dawn of the twentieth century. Female workers were of interest to economists because of social policy issues, such as wage equity, the minimum wage, and maximum-hours laws. Edith Abbott was among the most prolific of the economists researching women in the early $1900 \mathrm{~s}^{8}$ She was also a historian who reminded her readers that lower-class women had always worked if not in the market then at home, and that they faced a life no different from that

\footnotetext{
${ }^{6}$ See Goldin (1990), table 5.2 for data on the wage (uncompensated) elasticity ( $\eta$ ), the own-substitution (compensated wage) elasticity $\left(\eta^{\mathrm{s}}\right)$, and the income elasticity $(\varepsilon)$ as estimated in eight cross-city studies from around 1900 to 1970 and one time-series study for 1950 to 1980 . The own-substitution (compensated wage) elasticity $\left(\eta^{\mathrm{s}}\right)$ is calculated from the Slutsky equation: $\eta=\eta^{\mathrm{s}}-\alpha \cdot \varepsilon$, where $\alpha=$ wife's full-time income divided by husband's (or family's) actual income.

${ }^{7}$ Positive supply shifters include the greatly increased education of young women, decreased fertility, the greater number of "nice" jobs for women, and the related change in norms regarding women's work.

${ }^{8}$ Edith Abbott published thirteen articles in the Journal of Political Economy from 1904 (two years before she received her Ph.D. in economics from the University of Chicago) to 1911 (nineteen from 1904 to 1925), and she had six in the American Journal of Sociology from 1908 to 1911. She also published about twenty books in her lifetime, most of which concerned progressive social reform issues such as housing, immigrants, crime, prisons, and truancy, in addition to women's employment and its history.
} 
of their grandmothers. But the woman's movement, the first generations of college women, and the drive for the franchise held the promise of real change for Abbott, who observed that middleclass workingwomen were embarking on a "social revolution" (Abbott 1906). Richard T. Ely, a founder of the American Economic Association, its first secretary and sixth president, and whom this lecture memorializes, called the period the "Era of Woman" and in reaction to a call for restrictions on women to protect men's jobs averred, "Revolutions do not go backward."9 Despite the optimism of Abbott and Ely, the revolution in women's work would take another seventy-five years and some today believe it is going backwards, a view I will evaluate in this essay.

B. Phase II: 1930s to 1950_Easing the Constraints on Married Women's Work From 1930 to 1950 the labor force participation rate for married women 35 to 44 years old increased by 15.5 percentage points, or from about 10 percent to 25 percent (Figure 1 ). Whereas just 8 percent of employed women were married in 1890, 26 percent were in 1930 and 47 percent were in 1950. The fraction of single women in the labor force had not declined by much. Rather the labor force participation of married women had increased substantially.

The shift from Phase I to Phase II came about because of several complementary factors that were, in large measure, exogenous to female labor supply. The most important were the greatly increased demand for office and other clerical workers beginning in the early 1900s with the arrival of new types of information technologies and the enormous growth in high school enrollment and graduation from 1910 to 1930. The fraction of the female labor force (non-farm) employed as clerical workers rose from 6 percent in 1900 to 23 percent in 1930; whereas women

\footnotetext{
${ }^{9}$ Helen Campbell (1893, pp. v, vii). The aphorism is apparently due to President Abraham Lincoln but in the 1890 s it may not have required a reference since it was so well known.
} 
were 24 percent of clerical workers in 1900 they were 52 percent of them in $1930 .{ }^{10}$ Nationwide, high school graduation rates increased from 9 percent in 1910 to 27 percent in 1928. In the states outside the South the increase was from 11 percent to 32 percent and to 56 percent by $1938 .^{11}$

Both the increased demand for clerical workers and the increased supply of high school graduates meant that, prior to marriage, young women entered nicer, cleaner, shorter-hour, and thus more "respectable" jobs. Some remained employed after marriage, although levels were insubstantial until the 1940s. Part of the exodus at marriage was due to the institution of marriage bars, which were regulations that forced single women to leave employment upon marriage and barred the hire of married women. These bars existed in many school districts and some clerical employments especially in the 1930s but were almost entirely eliminated after the early 1940 s. $^{12}$

As work for women became more accepted, particularly by their husbands, the income effect declined. At the same time the substitution effect rose substantially. One of the reasons for the increase substitution effect concerns the rise of part-time work. Although weekly hours of work had been substantially reduced from 1900 to 1930 , part-time work was a rarity. ${ }^{13}$ The absence of hours and days flexibility placed bounds on the substitution elasticity. As the real wage for women rose, the margin of change was participation, not hours. In consequence a smaller increase in both hours and employment could occur than had there been greater

\footnotetext{
${ }^{10}$ See Goldin (1984) on the switch from manufacturing to clerical positions and the relative roles of supply and demand.

${ }^{11}$ The "high school movement" is discussed in Goldin (1998).

${ }^{12}$ On marriage bars, see Goldin (1991b).

${ }^{13}$ Hours of work in private, non-agricultural employment decreased from about 60 per week in 1900 to below 45 per week in 1930, just before the large, and mainly temporary, decline during the Great Depression (Goldin 2000). On the paucity of part-time work in the pre-1940 era see Goldin (1990, chapter 6).
} 
flexibility in hours (and days) of work. With the creation of scheduled part-time work in the 1940s and its enormous diffusion in the 1950s, the substitution effect became larger. Reinforcing factors include the almost complete diffusion of modern, electric household technologies, such as the refrigerator and the washing machine and the previous diffusion of basic facilities such as electricity, running water, and the flush toilet. ${ }^{14}$ The reduced price of these appliances served to decrease women's reservation wage and increase the elasticity of the aggregate female labor supply function.

The reason for the increase in female labor force participation during Phase II is complicated by changes in both the income and substitution elasticities of female labor supply. The factors responsible for increased female labor force participation in the early part of the phase were primarily shifts in the labor supply function, similar to the discussion for Phase I, since supply was rather inelastic. But in the second part of Phase II, labor supply became more elastic and both supply and demand shifts played a role in increasing female participation. As labor supply became even more elastic, as will be discussed for Phase III, labor demand shifts would swamp those on the supply side.

As married women began to enter the labor market in greater numbers, labor economists analyzed female labor supply decisions in the context of the family unit, rather than the individual, and inquired about the influence of husband's income on wife's "gainful

\footnotetext{
${ }^{14}$ Jeremy Greenwood, Ananth Seshadri, and Mehmet Yorukoglu (2005, figure1), who emphasizes the role of household technology in increasing women's labor market participation, has compiled data on adoption percentages for "basic facilities," such as electricity and indoor plumbing, and household electrical appliances. Most basic facilities had been adopted in 60 to 90 percent of households by 1950 . In terms of appliances 80 percent had refrigerators by 1950, and about 60 percent had vacuum cleaners and electric washers. Omitted from this work is the use of market substitutes for home appliances. About 70 percent of the households in the 1917/19 Cost of Living Survey, which included primarily middleincome families, used commercial laundry services and spent enough to do 6 to 7 pounds per week; 33 percent ate meals in restaurants; and 16 percent employed servants (Moehling 2001).
} 
employment." ${ }^{15}$ Interest initially emerged from an investigation of backward bending labor supply functions by Paul H. Douglas (1934, 1937 with Erika H. Schoenberg). By exploring the labor supply of men and women across cities Douglas noticed that married women's gainful employment was negatively related to husband's income. The evidence suggested a rather large income effect, "a freeing of married women from the necessity of working outside the home" (1937, p. 61). But this large negative income effect would soon begin to decline in (absolute) magnitude. Had it not, married women's labor force participation would never have greatly increased.

C. Phase III: 1950s to 1970 s—-Roots of the Revolution Married women's labor force participation continued to expand in the 1950s to 1970s, greatly at first for an older group of women (45 to 54 years old) and with soaring rates later for a younger group ( 25 to 34 years old). For married women in the 35 to 44 year old group, participation increased from 25 to 46 percent from 1950 to 1970 (Figure 1).

In the 1940s and 1950s female labor supply had become considerably more elastic and thus more responsive to changes in wages. At the same time, the income effect continued its downward trend as work for married women became more acceptable. ${ }^{16}$ The average married workingwoman by the 1940s was more educated that the average married women in the population, a reverse of my previous observation and another indication that the substitution effect had begun to swamp the income effect.

Many factors contributed to the increase in the own-wage elasticity. One was the

\footnotetext{
${ }^{15}$ The distinction between labor force participation and "gainful employment" is that the former concept was introduced with the 1940 census, whereas previously the question asked was the occupation in which the individual was "gainfully employed."

${ }^{16}$ See Goldin (1990, table 5.2) for labor supply elasticity estimates from 1900 to 1980. The evidence for 1940 to 1960 relies on cross-city estimates from the work of Bowen and Finegan (1969), Mincer (1962), and Cain (1966).
} 
creation of scheduled part-time employment. The availability of part-time work by firms led to an increase in those working less than 35 hours per week from 18 percent of the female labor force in 1940 to 28 percent in 1960 and from 14 percent of the female sales sector in 1940 to 40 percent in 1960. Another factor was the greater acceptance of married women in the labor force and the almost complete end of marriage bars.

Labor supply had become sufficiently elastic and the income elasticity sufficiently small that most of the increase in female labor force participation and hours of work during Phase III was demand driven. The demand function for labor increased rapidly over a relatively stable and highly elastic female labor supply function.

But despite large gains in employment, married women were still the secondary earners in their households. They took the labor supply decisions of their husbands as given; they were tied stayers at times and tied movers at others. Their human capital continued to increase, but the investments occurred mainly off the job in formal education or vocational training, rather than on the job. Secretaries, teachers, nurses, social workers, and librarians, among others, came to their jobs with most of the necessary skills. Some advancement was possible in offices and elsewhere but not much, according to most estimates of earnings functions. Interviews for first jobs, even those of college graduate women, often began with the straightforward question: "How well do you type?"17

\footnotetext{
${ }^{17}$ In a U.S. Department of Labor, Women's Bureau survey of college women who graduated in the class of 1957, a surprisingly large fraction remarked that they were asked how well they could type in their first job interview (Source: 1957/64 College Graduate Survey, see Goldin 1990, p. 230). Supreme Court Justice Sandra Day O'Connor has often recounted that her first job interview, obtained through personal contacts, after graduating near the top of her 1952 Stanford Law School class landed her a position as a legal secretary and no California law firm offered her a position as a lawyer. In Rona Jaffe's best-selling novel and movie, The Best of Everything (1958), the main character graduated from Radcliffe in the 1950 s and assumed a secretarial position in a publishing house with the hopes of becoming an editor. Among college graduate women 30 to 34 years old in the 1950 U.S. federal population census, 9.7
} 
Even though many would eventually be employed for a significant portion of their lives, their expectations of future employment, when they were young, were quite different. Women born from 1931 to 1940, for example, were eventually employed for more than 40 percent of their post-schooling years (up to around age fifty); the figure is 55 percent for those born from 1941 to $1950 .{ }^{18}$ Most of these women had anticipated brief and intermittent employment in various jobs, not generally in a career. Some trained for the remote possibility that they would have to support themselves later in life. College, for many, was a way to meet a suitable spouse rather than a way to embark on a career. Their investments in education and training were consistent with their expectations. But they were in for a great surprise.

The Phase III decades were ones of great expansion of the female labor force and also immense strides in modern labor economics. Clarence Long (1958) picked up where Paul Douglas had left off. ${ }^{19}$ Long was an empirical economist who explored the large increase in married women's labor force participation from 1890 to the 1950s and was puzzled by an apparent inconsistency. Cross-section labor supply estimates for 1940 from the U.S. census and for 1951 and 1956 from the Current Population Reports revealed substantial negative effects from increases in husband's income. ${ }^{20}$ The time series data clearly showed growth in female labor supply. Because husbands' income had increased substantially the two findings were apparently inconsistent. Long's attempt to resolve the paradox between the cross section

\footnotetext{
percent were secretaries and 19 percent were clerical workers. The occupation of "secretary" was the second most numerous behind teaching and was slightly more important than that of "nurse."

${ }^{18}$ These figures are calculated from the Panel Study in Income Dynamics (PSID), 1968 to 2003, and are for the unweighted sample of white women.

${ }^{19}$ John D. Durand (1948) also added to the literature on the causes of change and emphasized altered customs and norms fostered by what he termed "the succession of generations."

${ }^{20}$ Clarence Long (1958, chapter 7) used aggregated data at the city level. The 1950 census published tables were not yet available. Note that Long did not directly consider the existence of a substitution effect in addition to an income effect. Although he tried to assess the effects of increased female education he compared the relative levels of education for older men with those of various groups of women rather than assessing the differences these levels meant for women's employment and earnings.
} 
estimates and the time series data was to argue that the female labor supply function shifted outward and to explore some of the reasons, such as advances in household production. He concluded that although these factors moved in the right direction, their magnitude was insufficient.

Jacob Mincer (1962) resolved the apparent paradox between the time series and cross section results by considering both the income and substitution effects. ${ }^{21} \mathrm{He}$ also recognized that individual-level cross-section estimates of the income effect would be potentially biased upwards for use in time-series simulations. The reason was that husband's incomes in cross section contain a transitory component to which wives would respond, whereas the time series averages had less of the transitory and more of the permanent component. According to Mincer, the use of city-level data reduced the transitory component of husband's income and produced coefficient estimates appropriate for use in the time series simulation. The resulting substitution effect was considerably greater than the income effect and the apparent paradox was resolved. As real incomes rose, the labor force participation rate of married women increased even though the earnings of women relative to those of men advanced only slightly.

Major advances in labor economics, mostly associated with the work of Gary Becker, extended the analysis of women as part of a family unit. ${ }^{22}$ Fertility became an endogenous variable; marriage was analyzed as a market; divorce was a possibility and a threat point. The

\footnotetext{
${ }^{21}$ Mincer, in an interview with me in 2002, recounted the course he took from Albert Rees during his post-graduate stint at the University of Chicago. "Al Rees spent that particular quarter reporting on the book by Clarence Long ... [and] this paradox that if the husband's income was high the woman was unlikely to be in the labor force. But over time income grew for both husband and wife, and there was an increase in participation rather than a decrease ... I was sitting in Al Rees' class and I asked myself "what about taking two variables rather than one?" We had income and prices or wages. Shouldn't that tell what was going on? It could, if the price effect was stronger than the income effect. But then you have to bring in the family."

${ }^{22}$ See Gary S. Becker (1981), although many of the articles on marriage, fertility, and the family were first published in the 1960s and 1970s.
} 
family was the optimizing unit with the family utility function optimized by the altruistic family head. $^{23}$

III. The Quiet Revolution-Phase IV: Late 1970s to the present

A. Revolutionary indicators

Most labor force participation measures do not divulge that there was a revolution in women's economic status since the late 1970s. An exception is the labor force participation rate for married women (20 to 44 years old) with a child under the age of one year, which soared from 0.20 in 1973 to 0.62 in $2000 .^{24}$ But in general participation rates for married women, as well as rates for the fraction working full-time, reveal only small increases in the past several decades. $^{25}$ In contrast, married women's labor force participation increased greatly in evolutionary Phases II and III. As I discussed earlier, the labor force participation rate, by itself, is not a reliable indicator of a social and economic revolution. The increase in participation during Phase III, however, was to become an important precondition for the quiet revolution for reasons that will become clear.

If soaring participation rates are a precondition but not a sign of the revolution, then what are its indicators? Revolutionary indicators are found in various series that reflect the three

\footnotetext{
${ }^{23}$ On bargaining models within households that do not posit an altruistic head, see the seminal work of Marjorie B. McElroy and Mary Jean Horney (1981), as well as a novel version by Shelly Lundberg and Robert A. Pollak (1993).

${ }^{24}$ March Current Population Survey (CPS), for white non-Hispanic women. A decline since the year 2000 may be apparent to some but it has lasted for too brief a period and in too sluggish a macroeconomy for any definitive statement concerning whether the labor force participation rate of mothers with infants has declined.

${ }^{25}$ The decreases in the last five years are probably due to macroeconomic phenomena since participation rates for men have also dropped.
} 
changes mentioned previously: horizon, identity, and decision-making. ${ }^{26}$ I will mainly discuss the first two. In almost all cases the turning points of the indicator series are strikingly similar by cohort. For marriage age, college graduation, and professional school enrollment, the turning points were all around 1970. Changes in occupations occurred in the early 1970s. For earnings relative to comparable men, the turning point was a bit later, around 1980. Expectations regarding future work, social norms concerning women's family and career, and factors accounting for women's life satisfaction began to change in the late 1960s and 1970s. Some of the changes were preconditions for others, such as college majors, professional school enrollment, and occupational change. Their synchronicity should not be surprising. The series, taken together, present a logical progression.

\section{Expanded horizons}

By expanded horizons I mean that women more accurately anticipated their future work lives. ${ }^{27}$ With more accurate expectations they could better prepare by investing in formal education and they could assume positions that involved advancement. That is, they could plan for careers rather than jobs.

The revolutionary phase began with cohorts born in the late 1940s who were teenagers in the mid-1960s. These young women began to perceive that their adult lives would differ substantially from those of their mothers' generation. Their expectations of future employment when they were in their mid to late teens can be gleaned from the National Longitudinal Survey

\footnotetext{
${ }^{26}$ On decision-making and bargaining during Phase IV, see the evidence in Dora Costa and Matthew Kahn (2000), which suggests greater equality in location decisions, at least among college graduates. That bargaining with one's employer may not be female-friendly, see Linda Babcock and Sara Laschever (2004).

${ }^{27}$ They did not, however, do a very good job forecasting their future family size. A far greater fraction of women in the College and Beyond data set (to be discussed) responded as freshmen (in the Astin survey) that they expected to have children than actually did -82 percent (at about 18 years old) said they expected to have children but only 69 percent actually did (by 37 years old).
} 
of Young Women, which began with 14 to 24 year olds in 1968, and the National Longitudinal Survey of Youth, which began with 14 to 21 year olds in 1979. Both surveys asked similar questions about expectations of paid employment at age 35 . Their responses can be linked by respondent age to see how expectations changed over time for young women of various ages (Figure 2).

Young women in their late teens, during the 1970s, upwardly revised their expectations of being in the paid labor force when they were older. They began with expectations similar to the actual participation of their mothers' generation (their prediction was around 0.33 whereas their mothers' actual rate was about 0.3 ). But in the next ten years young women began to correctly anticipate, and in fact slightly overstate, their future labor force participation rates. By 1974 young women were predicting their participation rate to be in the 0.55 to 0.65 range. Actual rates for 35 year olds had risen to 0.46 in 1974, but women in their late twenties had experienced large increases in the early 1970s, suggesting greater future advances for those in their thirties. By the late 1970s young women were predicting participation rates above 0.80 , whereas the actual rate in 1978 was 0.56 . By the time the NLS youth were thirty-five years old the participation rate was about $0.75 .^{28}$ Young women gained horizon and perceived that their lives would differ from their elders. ${ }^{29}$ Their revised expectations of future employment, in turn, led young women to continue with college and graduate. ${ }^{30}$

\footnotetext{
${ }^{28}$ Actual labor force participation rates are from the CPS and are for married, white women averaged for ages 34 to 36 . The figure of 0.3 for their mothers is for 1962. Data from the two NLS surveys are for white females only.

${ }^{29}$ Young women in the early 1970s may have been enabled to make more informed extrapolations because the resurgence of feminism at the time supported challenging older ways and norms.

${ }^{30}$ Goldin, Lawrence F. Katz, and Ilyana Kuziemko (2005) find that among female pre-college teens (who were 14 to 18 years old in 1968) those who stated that they would be in the labor force when they were 35 years old had eventual college graduation rates that were 14.3 percentage points higher than those who said they would be "at home, with family" at age 35 years. Those in the former group had a mean graduation rate of 32.8 percent whereas the mean graduation rate for the latter group was 18.5 percent.
} 
Girls, in the 1970s and 1980s, began to take more college preparation courses in high school and narrowed the gap between their science and math course-taking and that of boys. Relative to boys, girls increased their aptitude scores in math and reading. They increased their math scores by one-quarter of a standard deviation and their reading scores by one-fifth of a standard deviation, so that in 1992 girls who were high school seniors were just slightly behind boys in math and considerably ahead in reading. ${ }^{31}$

In consequence, females greatly increased their college going and graduation rates relative to males beginning with birth cohorts in the late 1940s. For the earliest birth cohorts shown in Figure 3, from 1877 to the 1910s, college attendance rates were fairly equal, in part because women often attended two-year teacher training schools. With the cohorts born in the late 1910s and 1920s large differences emerged between male and female college going and graduation rates. From the cohorts born in the 1930s to the late 1940s males had a 10 percentage point lead in attendance and almost the same for graduation. But with the cohorts born in the late 1940s the lead was swiftly eliminated for both attendance and graduation.

A set of related changes during the same period occurred to college women. The median age at first marriage increased by an astounding 2.5 years for college graduate women born between 1949 and 1956, that is for those married in the early 1970s to those married in the early 1980s (Figure 4). The age at first marriage continued to climb by another year during the next decade. A similar increase in the age at first marriage also occurred to women who attended but did not graduate from a four-year college.

The median college graduate woman from the 1950s to the early 1970s was married

\footnotetext{
${ }^{31}$ The relative increases in math and science courses and math and reading aptitude test scores are from a comparison of the NLS72 and the NELS88. The changes are consistent with those from the National Assessment of Educational Progress (NAEP), although somewhat larger, and U.S. Department of Education transcript surveys (Goldin, Katz, and Kuziemko 2005).
} 
within a year after college graduation—at 22.5 years old. But by the early-1980s the median college graduate woman married at 25 years old. With a later age at first marriage women could take college more seriously. Most women who had married within a year of graduation must have met their future husbands while in college, possibly in the same college. Although some aspects of college social life did not differ much across these generations, the pressure to meet a spouse while in college diminished considerably.

Not only did women increase their attendance and graduation from college more than did men, they also began to close the gap with men in college majors. Whereas in 1970 a standard dissimilarity index for college majors between men and women exceeded 0.5 , it fell to about 0.3 in 1985 (Goldin 2005). Both men and women increased their majors in business administration, but women did to a greater extent and reduced their concentrations in the more traditional female fields of education, literature, languages, and home economics. Women's majors shifted from those that were "consumption" related to those that were "investment" related.

Women also began to further their education in professional and graduate schools around 1970 (Figure 5). Whereas in the late 1960s one in twenty entering law school students was a woman, two out of five were in 1980, and parity was reached in the early 2000s. A similar trend occurred for medical students. The increase in the fraction female also rose for other professional programs including dentistry, business administration, veterinary medicine, optometry, and pharmacy. Most important is that the turning points for the four professions given in Figure 5 all occurred during the early 1970s.

With longer and more informed horizons, years of accumulated job experience increased and the returns to job experience increased as well. Most estimates of returns to experience from the 1970s and 1980s show that returns increased for women by a very large amount but that 
returns increased by a rather small amount for men. ${ }^{32}$ Greater and more appropriate levels of human capital investment are one possible reason why returns to job experience increased for women relative to men. Other possible reasons include antidiscrimination laws and governmental interventions to enforce them.

\section{Altered identities}

The revolution can also been seen in the changed outlook of women concerning their individual identities. As women married later, they could "make a name" for themselves before having to chose to change their name. In the 1970s and continuing to the 1980 s more women retained their surname upon marriage, particularly among those who had advanced degrees. Virtually all married women took their husband's name in the early 1970s. By 1990 about 20 percent of all college graduate women retained their surname at marriage, although during the 1990s the percentage declined somewhat (Goldin and Maria Shim 2004).

Ever since the mid-1960s a significant fraction of American college freshmen have been surveyed about their future personal satisfaction and the relative roles of family, finances, community, meaningful philosophy of life, helping others, and career success. Beginning in the early 1970s, women placed greater emphasis on coworker recognition and career success in the factors they believed would be important to their personal satisfaction and they placed far less emphasis on their concern with others. ${ }^{33}$ Their responses, moreover, became more similar to

\footnotetext{
${ }^{32}$ On the increase in returns to experience see Francine Blau and Lawrence Kahn (1997), Claudia Olivetti (2001), and June O'Neill and Polachek (1993). On the increase in hours of work due to the increase in returns, see Olivetti (2005). Although all agree that returns increased more for women than men, the magnitudes reported differ. Blau and Kahn, and O'Neill and Polachek report a doubling of the returns to women. Olivetti shows for a somewhat longer period (1970s and 1990s) that women's returns increased by around 25 percent and men's by from 6 to 9 percent.

${ }^{33}$ Concern with others can be observed in the objectives "helping others who are in difficulty," "participating in community action program," and "helping to promote racial understanding." All of these objectives declined in importance and fell more for women than men in terms of their overall significance to the individual.
} 
those of comparable men entering college. In the Survey of American Freshmen (Alexander W. Astin, et al. 2002), females increased the weight they placed on recognition by colleagues and financial success; males increased their relative weight on family (Figure 6). By the early 1980s men and women gave about equal weight to recognition and family. Women had changed considerably and were far more concerned with their own personal success and family, although men still placed more weight on financial success.

Alterations in identity are reflected in continued changes to the parameters of the Slutsky equation. Both income and substitution elasticities decreased substantially in (absolute) magnitude for all education groups of women in the 1980s and again in the 1990s. ${ }^{34}$ The decrease in the income elasticity continued its twentieth century trend downward. The decrease in the substitution effect sharply reversed its trend upward in the first two-thirds of the century. ${ }^{35}$ By the 1990s income and substitution effects of the labor supply function, while still somewhat greater for women than for men, were more similar than estimated values at any other time.

Changes in the income and substitution effects reflect a fundamental transformation in how women view their employment. Rather than jobs, most see employment as part of a longterm career. Most perceive their work as a fundamental aspect of their satisfaction in life and view their place of work as an integral part of their social world. They have added identity to their decision about whether to work or not to work given changes in wages and incomes. In consequence women have become stickier in their labor force attachment. Leaving the workplace involves a loss in identity for a woman, just as being unemployed or retired has

\footnotetext{
${ }^{34}$ According to Blau and Kahn (2005) married women's own wage elasticity (with respect to hours of work) fell by 50 to 56 percent from 1980 to 2000 and the elasticity of hours with respect to husband's income fell by 38 to 47 percent. Similar results are found for participation. Their results are robust to alternative specifications and corrections for various types of selectivity bias.

${ }^{35}$ The unit of observation in Blau and Kahn (2005) is the individual whereas that in the eight studies for the pre-1970s period is the city. The Blau and Kahn finding of a reduction (in absolute value) in the two elasticities within the 1980 to 2000 period allows one to make inferences about the longer period.
} 
commonly involved a loss of prestige and social belonging to most men. Income and

substitution effects changed for women in low and high-income families alike and for those at almost all levels of schooling. Ethnographic research corroborates the empirical finding that low income and even poor women increased their attachment to the workplace as a source of personal identity. ${ }^{36}$

3. Relative earnings and occupations

The result of expanded horizons and altered identities was that younger cohorts of women were considerably better prepared to enter the labor market and were determined to have careers. These changes are reflected in their occupations and earnings relative to those of men. The earnings of women relative to those of men began to increase around 1980 after remaining flat since the 1950s (Figure 7). ${ }^{37}$ Much of the increase was due to women's greater job experience and to their more market relevant skills as reflected in the increased return to experience. $^{38}$ Occupations shifted, not surprisingly, from those that had been considered traditional ones for women, such as teacher, nurse, librarian, and social worker, to a varied group of professions including lawyer, physician, professor, and manager (Figure 8). But it has also been noted that even within cohorts the earnings of women increased relative to those of men, suggesting that change may have diffused to those in their middle-age and was caused, at least in

\footnotetext{
${ }^{36}$ Typical of the findings in the ethnographic literature is Lillian Rubin (1994) who did a similar study two decades before. "Universally, the women I interviewed work because they must. Almost as often they find a level of self-fulfillment and satisfaction on the job that they're loath to give up" (p. 81). With regard to changes in their sense of fairness in the labor market, Rubin writes: "Now all the women, even those who greeted the idea with reservations two decades ago, endorse the principle of equal pay without equivocation" (p. 83). With greater attachment to their positions, they demanded to be treated as the equals of men.

${ }^{37}$ The ratio of female to male hourly earnings is higher than that for full-time, year-round workers because men work more hours even among those working full-time.

${ }^{38}$ O'Neill and Polachek (1993) decompose the increase in relative earnings for women and find that increased returns to experience accounts for a larger fraction of the difference than the increase in work experience. They do not, however, explain the increase in returns to experience in terms of better preparation for the labor market or better treatment by the labor market.
} 
part, by changes within the labor market or imposed on it by anti-discrimination legislation.

B. What caused the revolution?

Jacob Mincer was right. In the 1950s and 1960s labor demand increased greatly and for women it raced across a relatively stable and rather elastic labor supply function. But many of the women in Phase III were caught by surprise. They had incorrectly anticipated their future labor force participation. They were often trapped in positions that involved little advancement. College women had majored in fields that were more consumption than investment oriented. Few had continued to professional and graduate schools.

But the next generation observed the large increase in participation and in full-time work of their immediate predecessors. They extrapolated on that basis to form more accurate expectations for their futures. In doing so they were better prepared to invest in human capital. As high school students they took more college preparation courses and their aptitude test scores rose relative to those of boys. They greatly increased their college attendance and graduation. At college they altered their college majors toward those that were more valuable in the labor market and less valuable at home, and they continued with post-graduate education to a far greater extent than did previous generations.

The age at first marriage for college women increased with cohorts born around 1950. Marriage delay enabled women to take formal education more seriously and led to changes in their relationship to work. The period divorce rate began to increase in the $1960 \mathrm{~s}$. The combination of the increase in divorce and the later age at first marriage for all women meant that the fraction of their lives they would spend married plummeted and economic independence became more valuable (Figure 9). These changes altered the identity of women and shifted it from a family and household centered world to a wider one that was more career oriented. 
One of the reasons for the increase in the age at first marriage was the introduction of the contraceptive "pill." Although the pill was approved by the Food and Drug Administration as a contraceptive in 1960 and quickly diffused among married women, young single women found it harder to obtain due to restrictive state laws. Legal changes at the state level, such as mature minor decisions and the increased age of majority that mainly occurred from the late 1960s and early 1970s, enabled young women to obtain the pill, even though the rulings and legal changes were not normally intended for that purpose. ${ }^{39}$ As the pill diffused through the young, unmarried population a potent reason for early marriage disappeared. With a larger group of single individuals others could afford to wait and a multiplier effect added to the increased age at first marriage. ${ }^{40}$ As the age at first marriage increased, women could be more serious in college, plan for an independent future, and form their identities before marriage and family. ${ }^{41}$

\section{Has the Quiet Revolution Stalled?}

A. Is there a "natural rate" of female labor force participation?

Female labor force participation rates and the fraction working full-time are no longer soaring, let alone rising. Participation rates for women of almost all ages, education levels, and marital statuses seem to have leveled off since around 1990 after rising non-stop for at least the last century (Figure 1). The participation rate of married college graduate women in their

\footnotetext{
${ }^{39}$ In fact, many states increased their age at majority after passage of the Twenty-Sixth Amendment to the U.S. Constitution in July 1971 that lowered the minimum voting age to eighteen.

${ }^{40}$ Goldin and Katz (2002) describe the model that generates an increased age at first marriage with the diffusion of the pill and provide evidence concerning the timing of the pill's spread among young women.

${ }^{41}$ Why divorce increased is a more contentious issue. Some thought the increase was due to the legal changes of the 1960s that relaxed divorce statutes in various states and allowed unilateral divorce. Others posited, along the lines of the Coase Theorem, that the legal changes should not have mattered. The empirical literature shows that the immediate effect of the laws was to increase divorce but that after a decade divorce rates revert to their initial levels. For a summary of the debate and an empirical analysis of the short and long-run effects of legal changes, see Justin Wolfers (2003).
} 
thirties, for example, has hovered around 76 percent since 1990. For high school graduate married women in their thirties a rate of about 72 percent has been sustained for the past fifteen years. ${ }^{42}$ Thus a plateau in female labor force participation appears to have been reached a decade and a half ago. ${ }^{43}$ The participation rate for women with infants may have even declined. These facts have led many to wonder if some type of "natural rate" of female labor force participation has been reached. Since participation rates are bounded above by one, the question is really whether the natural rate is lower than some had thought it would be.

Whether or not the data support a natural rate hypothesis depends on the particular age group examined. For women in their thirties, a natural rate does not appear to have been reached, even though a leveling off has occurred. The reason the evidence does not yet support the natural rate notion concerns changed demographics.

With a later age at marriage and a delay of child bearing, women in their thirties now have a higher probability of having a child under the age of six than they did twenty-five years ago and about an equal probability as in the mid-1960s (Figure 10). ${ }^{44}$ Despite this greater child burden, participation rates for women in their thirties are higher today than in the early $1980 \mathrm{~s}$ and far higher than in the 1960s. During the past two decades, the participation rate of this group has remained relatively stable and substantial. Thus, rather than peaking or declining, their participation rates appear to be keeping up given the changed demographics.

The participation rate for 33 to 37 year old married college women, for example, was 77

\footnotetext{
${ }^{42}$ The data given are from the March Current Population Survey (CPS). Similar data for women in their forties show slightly higher rates.

${ }^{43}$ The plateau in most labor force participation series began in the early to mid-1990s during a weak economy but was sustained during the boom economy of the late 1990s. Therefore, it would not appear that the macro-economy was solely to blame. The dip in participation in the early 2000s, however, was due to the low employment growth.

${ }^{44}$ The number of children per mother was greater in the past even though the fraction with children under the age of six years is greater today.
} 
percent in 1999 while the fraction with children under the age of six was 61 percent (Figure 10). ${ }^{45}$ In 1965 just 40 percent were in the labor force and 57 percent had children under six years old. Participation rates increased from 1965 to 1999 by 37 percentage points while the child burden actually increased, by 4 percentage points. ${ }^{46}$ From 1980 to 1999 participation rates rose 11 percentage points while the kid burden rose 12 percentage points, and from 1990 to 1999 both participation rates rose and the kid burden rose by about 2.5 percentage points.

The notion that a natural rate has been reached does not appear to be supported for these "thirty-something" year olds. Rather, these women appear to be committed to the labor force probably because they were in the labor force far longer before they married, invested more in formal and informal training, and shaped their identities before having children.

What about women in their twenties? Once again, consider the college graduate woman, this time for all marital statuses. Labor force participation rates for women 25 to 29 years old have been very high, in the 90 percent range through the 1990s, but these rates, too, have been very flat (and have, like others, declined a bit through the downturn of the early 2000s). As opposed to the group in their thirties and early forties, these women have not had any increase in their child burden. In fact, the fraction with young children declined substantially to the mid1980s and has been flat ever since. Thus both their participation rates and their child burdens remained fairly constant since 1990 at the latest. If a natural rate has been reached, then this group might provide confirmation. But, in the 1990s, participation rates of women in their late

\footnotetext{
${ }^{45}$ The rate was 74 percent in 2004. But in all cases, including that of men, participation rates from 2000 to 2004 were depressed relative to previous rates and reflect the sluggish labor market in general rather than anything specific to women. Because of the macroeconomic slowdown, I use 1999 data.

46 "Child burden" measures whether there is a child under six years old, not the number of children.
} 
twenties were not much different from those of comparable men. ${ }^{47}$

B. Opting out of the revolution?

Back in the 1950s when Americans were concerned that women were dropping out of college to get married, many questioned whether women should attend college at all. Recently, a similar issue has been raised. ${ }^{48}$ Even women who have graduated from the best universities and finest professional schools are reported to be fleeing the labor force for the comforts of home and family and the identities of mother and wife. Rather than being "pushed out" or "forced out," they have, according to some, made a conscious decision in their late twenties and early thirties to "opt out."49 Does the current evidence support the notion that the quiet revolution is unraveling?

To evaluate the opt-out assertion requires longitudinal or retrospective data of a sufficient time-span. The individual who opts out today may return to the workplace tomorrow and the woman who left the corporate law office yesterday may wind up on the city council in a year. Young women who see romance and comfort in being "stay at home Moms," may change their minds long before they receive their diplomas. The requisite data must also include a large number of female and male graduates from top-ranked institutions of higher education since the opt-out assertion generally pertains to women who, by virtue of their undergraduate institution, are thought to have opted for careers. A reasonable evaluation also requires comparisons with similar men.

\footnotetext{
${ }^{47}$ Further confirmation is provided by Heather Boushey (2005) who finds that the child penalty-the lower labor force participation of women with young children - decreased from 1984 to 2004, controlling for year effects and demographics.

${ }^{48}$ A moment of déjà vu can be found in a review by Caroline Hill in the Journal of Political Economy of Charlotte Perkins Gilman's book. Hill remarked: “The conservative has had his innings since about 1900 ... because a few highly educated women have abandoned their specialties for their families, they are used as illustrations of the futility of opening graduate schools to women" (Hill 1904, p. 410).

${ }^{49}$ See the New York Times magazine section article by Lisa Belkin (2003) on what she termed the "opt out revolution" and the firestorm that ensued in newspapers across the nation.
} 
The College and Beyond data set of the Andrew W. Mellon Foundation meets these stringent criteria. The data set consists of administrative data for individuals from thirty-four "selective" universities and colleges and the results of a survey. ${ }^{50}$ The entering class of 1976 is examined here because it is one of the latest college cohorts for which information exists to their mid-life. The survey was completed in 1995/96 when the respondents were around 37 years old by which time most of the women had completed their child bearing years, although career and other demographic transitions would continue. ${ }^{51}$ College and Beyond contains the largest sample of college graduates from selective institutions that currently exists with data relevant to the issues at hand. ${ }^{52}$ Using these data I explore out-of-work spells among college graduate women and how these spells were affected by family, further education, and occupation. ${ }^{53}$ Only non-education related spells are considered and only spells of more than six months were recorded in the survey.

In the more than fifteen years since receiving their baccalaureate degrees the median woman who graduated from one of the thirty-four selective colleges was never out-of-work for more than six months at a time, and that was true even among those who had at least one child

\footnotetext{
${ }^{50}$ Because of confidentiality requirements, the College and Beyond data set is restricted. I thank the Andrew W. Mellon Foundation for making the data available to me for this and other research. For more information on the College and Beyond survey, see the data appendix in William G. Bowen and Derek Bok (1998).

${ }^{51}$ After age 37 the probability of having any birth for a college graduate woman born from 1955 to 1959 was 0.136 , whereas the total number of births this group would have to age 44 was 1.424 . The probability of a first birth after age 37 for this group was 0.03 (Goldin, Katz, Qingyan Shang, and Bruce Weinberg in progress).

${ }^{52}$ Lawrence F. Katz, Bryce Ward, and I are currently compiling similar data for various entering classes beginning in 1969 from one highly selective college. These data will be more current than are those in the "College and Beyond" and will contain better demographic and occupational data.

${ }^{53}$ The College and Beyond data do not include information on the birth dates of the children. Only data on the number of children were collected, although the no-work spell information includes whether the spell was for "family reasons."
} 
(Table 1). ${ }^{54}$ The sum of all out-of-work spells was just 1.55 years; that for women with children was 2.08 years and that for women without children was 0.41 years or just 5 months. Among all women, less than one-quarter had out-of-work spells totaling two years or more and among women with children the figure is less than one-third. For most women, the sum of all out-ofwork spells during their first fifteen years after graduation was remarkably short. The spells were, to be sure, larger than those for comparable men who logged 0.244 years (or 3 months) total in out-of-work spells but they were, nonetheless, a small fraction of their years since graduation. Of the fraction of the time since graduation, not spent to advance their education, these women were away from work just 11 percent of the time, and only 7 percent were away from work for more than 50 percent of the time.

In a regression context, children were the most important factor related to out-of-work spells for women and a clear non-linearity exists in the impact of successive numbers of children. One child increased total time not at work by just 0.36 years on average, two children by 1.41 years, and three (or more) by 2.84 years. ${ }^{55}$ The opposite effect holds for men. The first child decreased out-of-work spells by 0.14 years, the next by 0.18 years, and beyond that by 0.21 years. Women with advanced degrees had far briefer spells than other women and the effect holds even for those with children. In fact, almost all of the difference between the out-of-work spells of those with advanced degrees and others is due to the shorter duration of their spells for having children. Those with medical degrees had the shortest no-work spells; doctorates were

\footnotetext{
${ }^{54}$ Because I include education spells for which the respondent also gave another reason (e.g., family responsibilities) out-of-work spells are likely to be a bit overstated.

${ }^{55}$ Coefficients on the number of children are from a regression including marital status, race, and the various professional and graduate degrees. Controls for college selectivity and the individual's SAT scores did not affect the estimates.
} 
next and then lawyers. African American women had the briefest spells of all. ${ }^{56}$

Evidence from the Current Population Surveys (CPS) and the College and Beyond data set does not indicate that college graduate women, particularly those from selective institutions, have opted out in significant numbers and that the phenomenon has increased. ${ }^{57}$ But because data, to be meaningful, must reveal the full longitudinal view from late in life, the path of the most recent generations cannot yet be judged. There are, however, some hints. Evidence on aspirations from the Astin freshman survey does not suggest major changes in the factors that young people expect will yield satisfaction in life. Data on the age at first birth from U.S. Vital Statistics shows a continued increase among college graduate women and a slight, but noticeable, increase in the number of births to those with four or more years of college. As for the validity of the opt-out theory, the jury must remain out for at least another decade.

V. Three Evolutions, the Quiet Revolution, and Beyond: A Summary

What forces propelled the three evolutions in the lives of adult women and brought about the quiet revolution? At the risk of simplifying a complicated social and economic transformation that unleashed the most momentous change in the labor force of the twentieth century, I will summarize my argument.

I separated the approximately first three-quarters of the twentieth century into three phases of evolutionary change. During Phase I, few adult and married women were in the labor force. The income elasticity of female labor supply was large (and negative) and the substitution

\footnotetext{
${ }^{56}$ Attendance at a woman's college decreased out-of-work spells but only because women's college graduates in this sample had fewer children, due in part because a lower percentage married.

${ }^{57}$ The opt-out thesis can also be evaluated with regard to whether women in the 1976 entry class who earned advanced degrees were in occupations in 1995 that were directly degree-related. The vast majority of women who trained to be medical doctors were employed as physicians when in their late thirties; the same is true for women who received law degrees and lawyers. Women in these graduating classes, moreover, stuck with their specialties to about the same degree as did comparable men.
} 
elasticity of labor supply was small. Virtually all change in participation had to come from shifts in labor supply. Until the two elasticities of the Slutsky equation changed, economic growth and the consequent increase in real earnings for women would not elicit an increase in the participation of adult and married women. But change they did during Phase II.

The income elasticity decreased considerably in (absolute) magnitude with the arrival of nice jobs that reduced the stigma surrounding married women's work outside the home and with the increase in high school attendance and graduation rates that made nice work a possibility for many young women. The substitution effect increased substantially with the reduction in hours (and days) of work, the initial stirrings of part-time work, and the rapid diffusion of the electric household. Also of some importance, although often exaggerated, was the impact of World War II in demonstrating, to women and their families, that the workplace could be respectable and showing employers that women were profitable to employ. ${ }^{58}$

By Phase III female labor supply was rather elastic. The large increase in aggregate demand, especially in the 1960s, and the accommodation of married women with the expansion of part-time work, led to an enormous increase in married women's labor force participation. Put succinctly, demand raced over an elastic labor supply function. But these changes could hardly have been accurately predicted by the participants. Most—even those with college degrees — had not made plans to be in the workforce for an extended period. Work was a job to "fall back on," not a career. The skill set of these women was not commensurate with their eventual life cycle labor force participation. But all of that would also change.

\footnotetext{
${ }^{58}$ Goldin (1991a) demonstrates the relatively short-lived nature of the increase in women's employment in the 1940s. Daron Acemoglu, David H. Autor, and David Lyle (2004) identify that female labor supply did shift because of war-time work. Using a similar identification strategy, Raquel Fernandez, Alessandra Fogli, and Olivetti (2004) find that wartime work not only increased female labor supply but had a multiplier effect through a change in work preferences. The sons of working women who lived through the early 1940 s were more willing to have a working wife.
} 
Young women growing up in the 1960s could see that adult and married women had participation rates that were rapidly increasing. The young began to extrapolate to their own lives, possibly influenced by the resurgence of feminism that cautioned them to think independently. Two other important changes took place. One was the contraceptive innovation known as the pill. Aided by changes in state laws, the pill diffused to young, single women. The other was the enormous increase in divorce in the 1960s. The advent of the pill for young women allowed them to plan their careers before planning for their families and to be taken more seriously by their employers and advisors. A consequence of the pill was that the age at first marriage increased. Together with the rise in divorce, a far smaller fraction of a woman's life would be spent married. Young women in the 1960s and 1970s were better able to predict what their future lifetime employment would be. As a result they increased their investments in formal schooling, majored in career-oriented subjects, and continued to professional and graduate schools in far greater numbers. They had longer horizons than did previous generations and an altered identity that placed career ahead or on equal footing with marriage.

Wives were less often secondary workers, the flotsam and jetsam of the labor market. The income and substitution effects of labor supply changed once again, mainly in the 1980s and 1990s. No longer was women's labor supply highly elastic. It was influenced even less than before by husband's earnings. The earnings of women rose relative to those of men, occupations changed from more traditional ones to those that had been considered nontraditional.

The quiet revolution was set in motion by the generation born in the late 1940s, but a noisier revolution, led by some in the older cohorts, preceded it. ${ }^{59}$ As opposed to the noisy revolution, the quiet revolution was accomplished by many who were unaware that they were

\footnotetext{
${ }^{59}$ The noisy revolution began in the 1960s as part of the Civil Rights and, somewhat later, anti-war movements. The younger cohorts transformed it in the early 1970s and created the women's liberation movement. See the excellent summary by Rosen (2000).
} 
part of a grand transformation. They were the unwitting foot soldiers of an upheaval that would alter women's employment, education, and family. But was Ely correct in asserting that "Revolutions do not go backward"? There is little evidence that this one has, at least for now. 
Figure 1

Labor Force Participation Rates for Females and Males by Age and Marital Status: 1890 to 2004

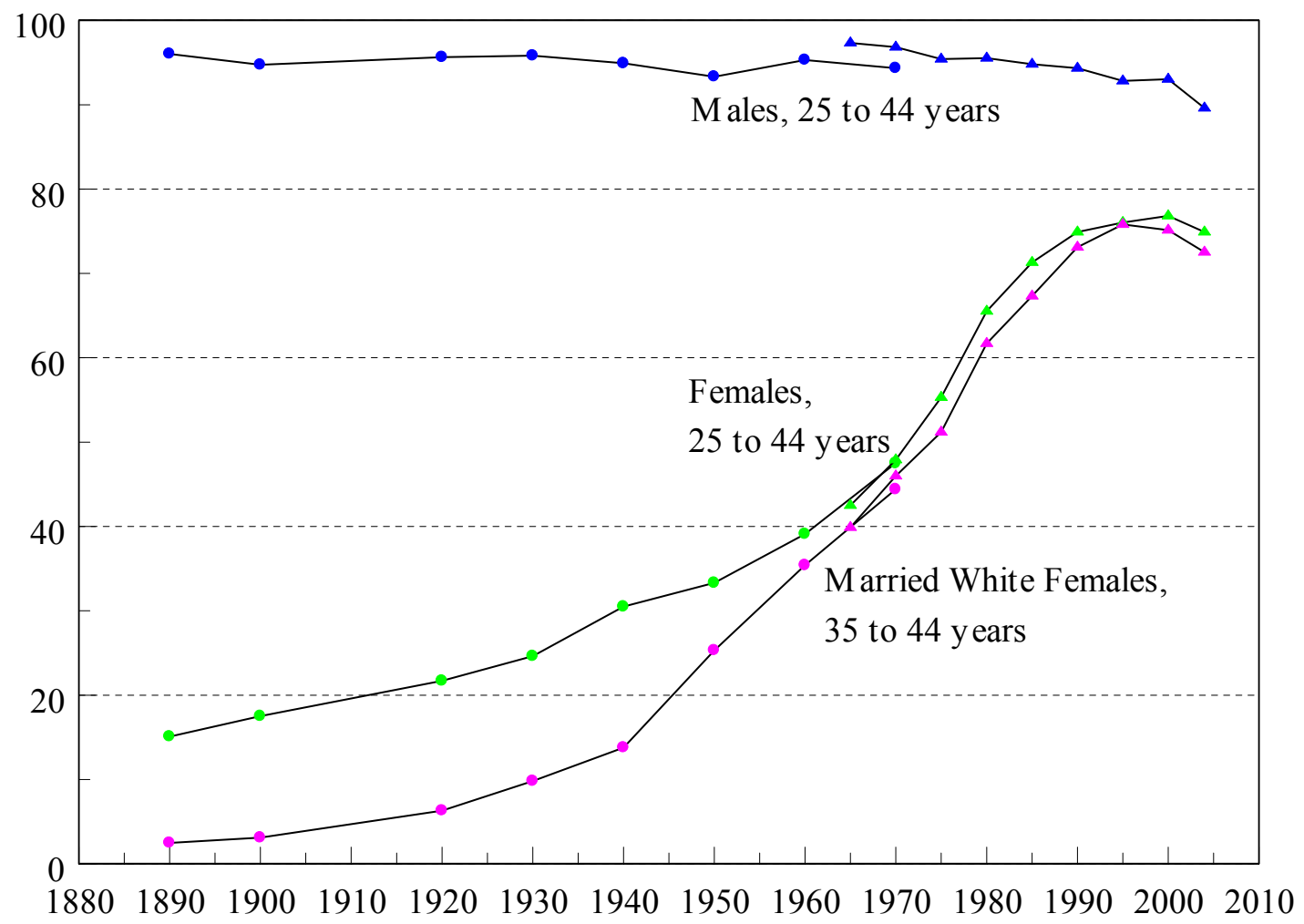

Sources: 1890 to 1970, Goldin (1990) from U.S. federal population census; 1965 to 2004, March Current Population Survey (CPS).

Notes: All races, marital statuses, and education groups are included unless indicated otherwise. The labor force participation rate from 1890 to 1930 is the fraction of "gainful workers" in the relevant population. The "dots" are from the census and the "triangles" from the CPS. The difference for females is small, somewhat larger for males. 
Figure 2

Employment Expectations of Female Youth by Age: 1967 to 1984

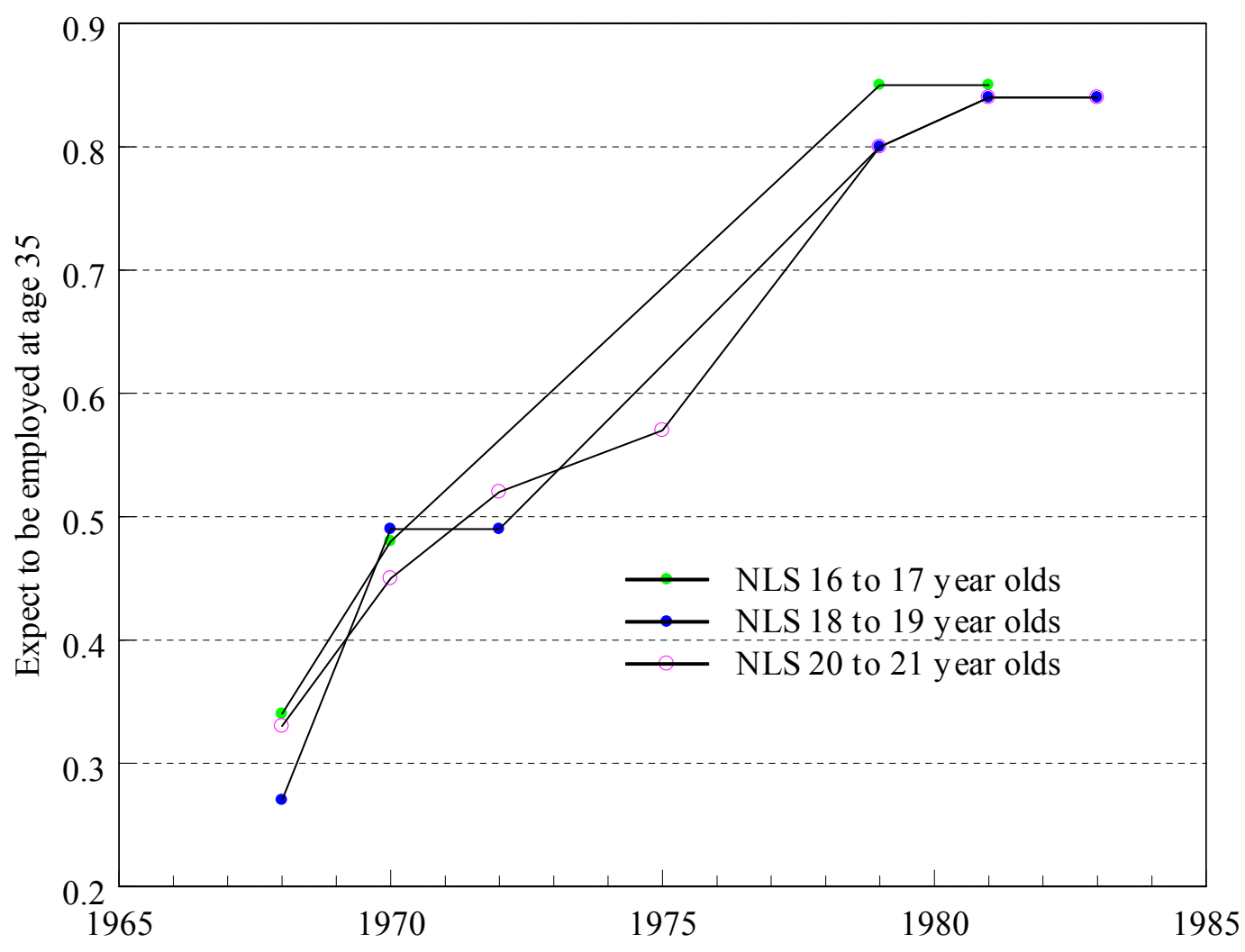

Sources: 1968 National Longitudinal Survey of Young Women (NLS68) and 1979 National Longitudinal Survey of Youth (NLSY). See Goldin (2005) for details.

Notes: The NLS data are the response to whether an individual stated she expected to be in the paid labor force at age 35 and are given here for white women. The NLS data link the averages for each age group over time. Thus, the 14 to 15 year olds in the NLS68 in 1968 became 16 to 17 years old in 1970 and are linked to the 16 to 17 year olds in 1979 in the NLSY. 
Figure 3

Female Minus Male College Attendance and Graduation Rates: Birth Cohorts, 1877 to 1974

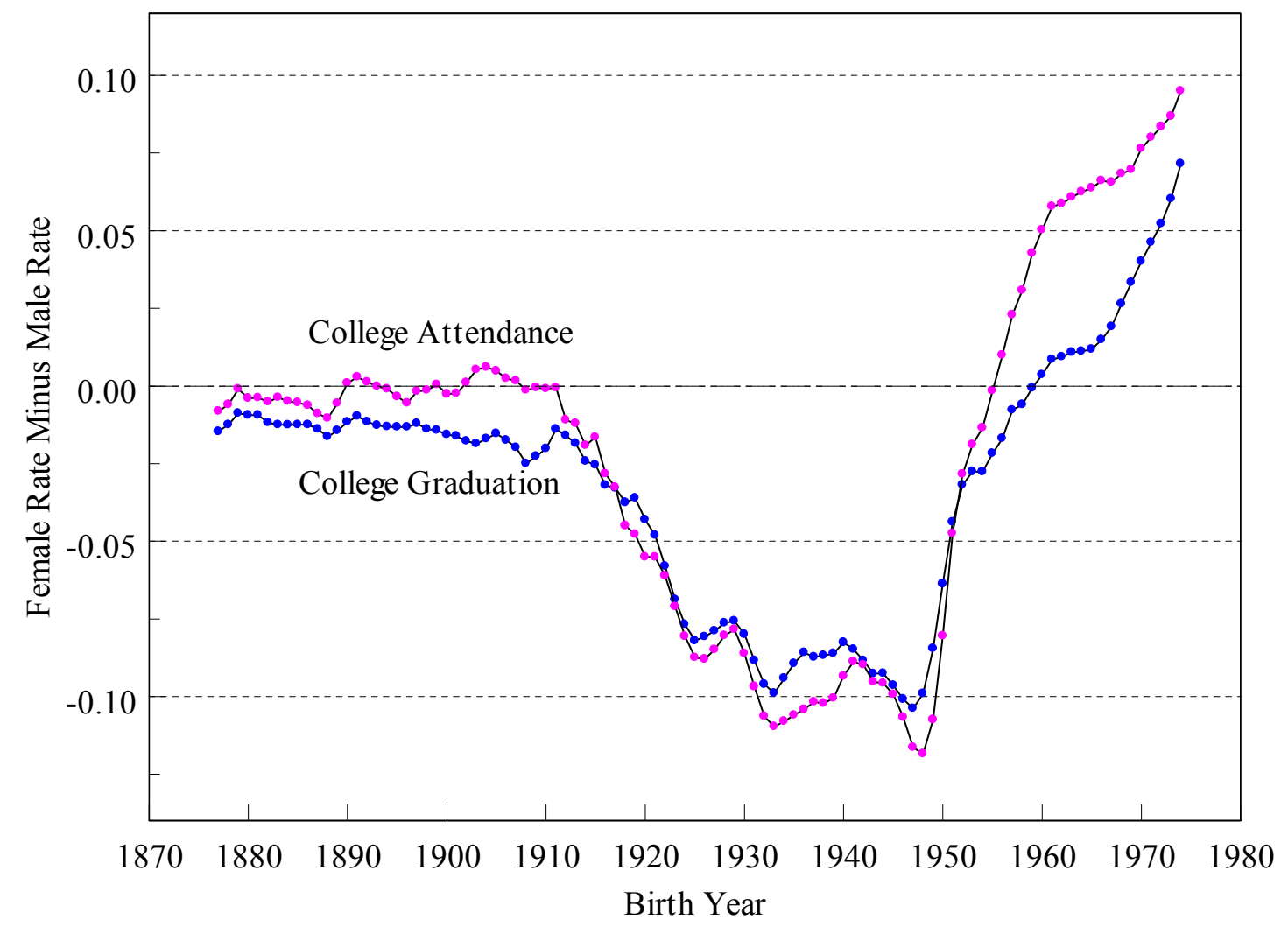

Source: 1940 to 2000 Census of Population Integrated Public Use Micro-data Samples (IPUMS).

Notes: The underlying data are the fraction of four-year college attendees or graduates by birth cohort and sex adjusted to 35 years of age for the U.S. born. College graduates are those with 16 or more completed years of schooling for the 1940 to 1980 samples and those with a bachelor's degree or higher in the 1990 to 2000 samples. The underlying samples include all U.S. born residents aged 25 to 64 years. For information on the age-adjustment regressions see De Long, Goldin, and Katz (2003, figure 1) and Goldin, Katz, and Kuziemko (2005). 
Figure 4

Median Age at First Marriage for Birth Cohorts of Female College Graduates and Attendees: 1931 to 1968 Birth Years

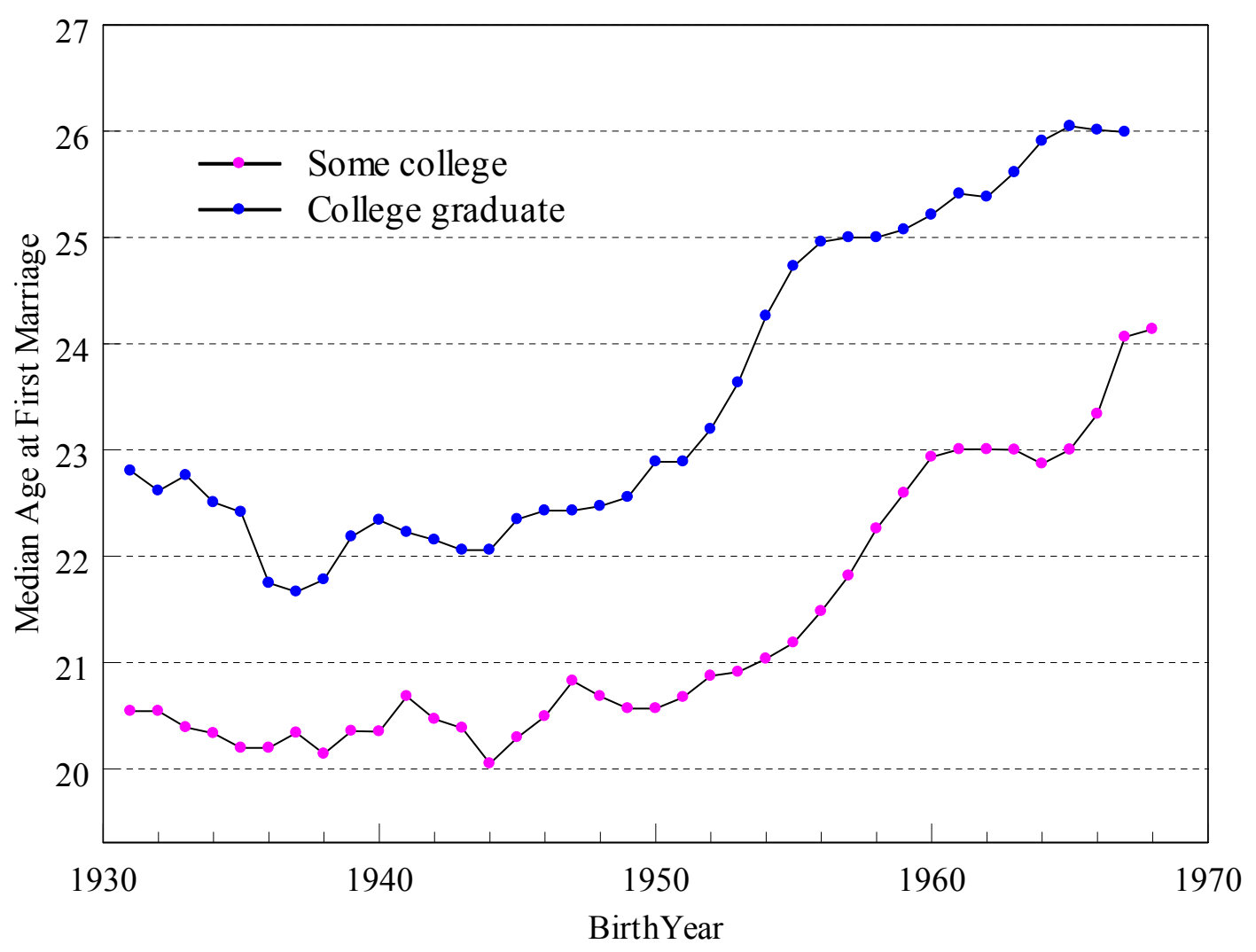

Sources: Current Population Survey, Fertility and Marital History Supplement, 1990 and 1995. Notes: Three-year centered moving averages are shown. 
Figure 5

Fraction Female among First Year Students in Professional Programs: 1955 to 2005

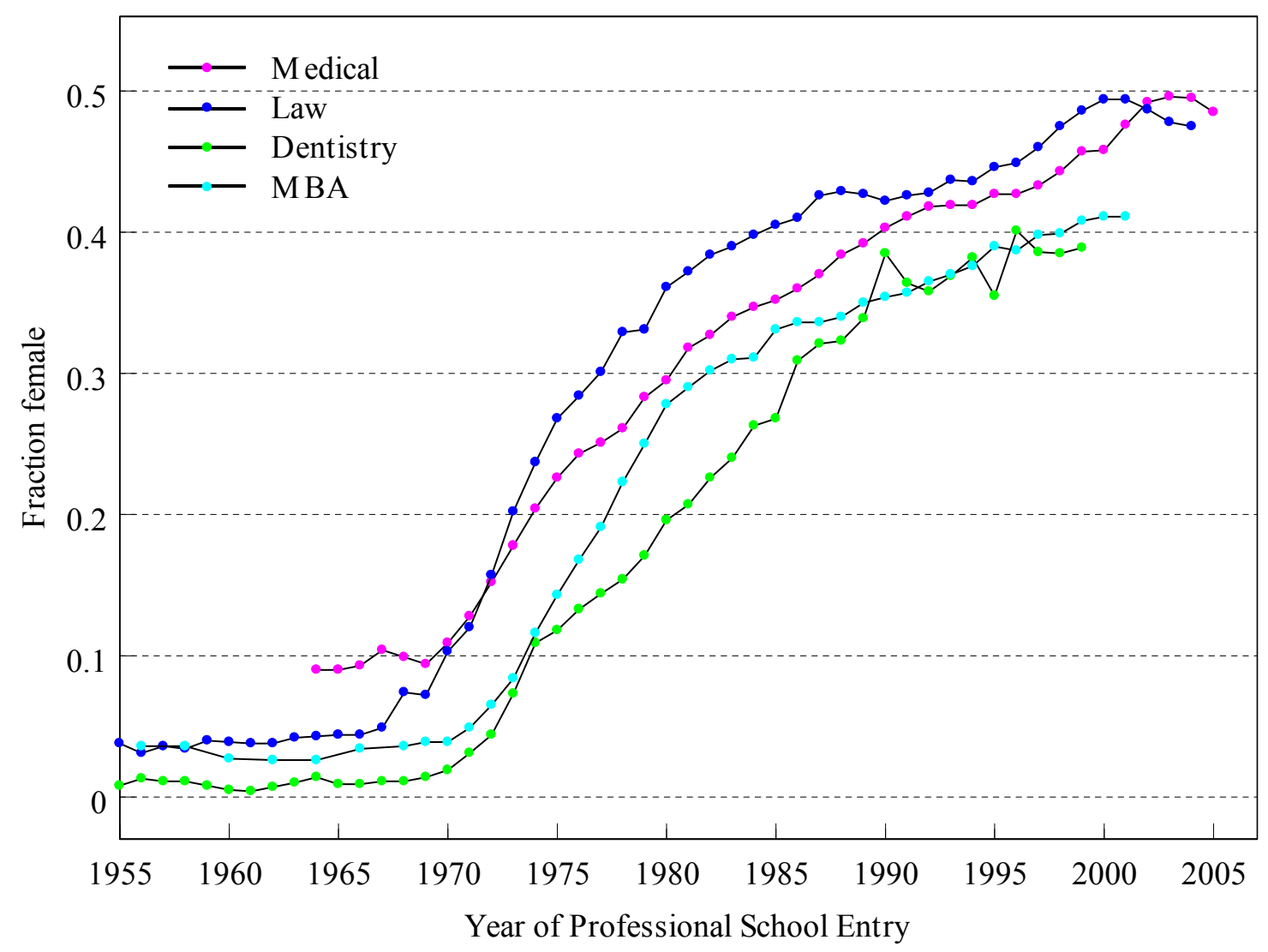

Sources and Notes: First-year law students from the American Bar Association website: http://www.abanet.org/legaled/statistics/femstats.html . First-year medical students (to 1994) from Journal of the American Medical Association (various years 1978 to 1998) and (from 1994 to 2005) from the American Association of Medical Colleges website http://www.aamc.org/data/facts/2005/2005summary.htm . First-year dentistry students extrapolated from dental degrees awarded lagged four years, from U.S. Department of Education, NCES (2005, table 257). Masters in Business Administration first-year students extrapolated from MBA degrees awarded lagged two years, from U.S. Department of Education, NCES (2005, table 278). 
Figure 6

Personal Satisfaction Factors for College Freshmen,

Differences by Sex: 1966 to 2000

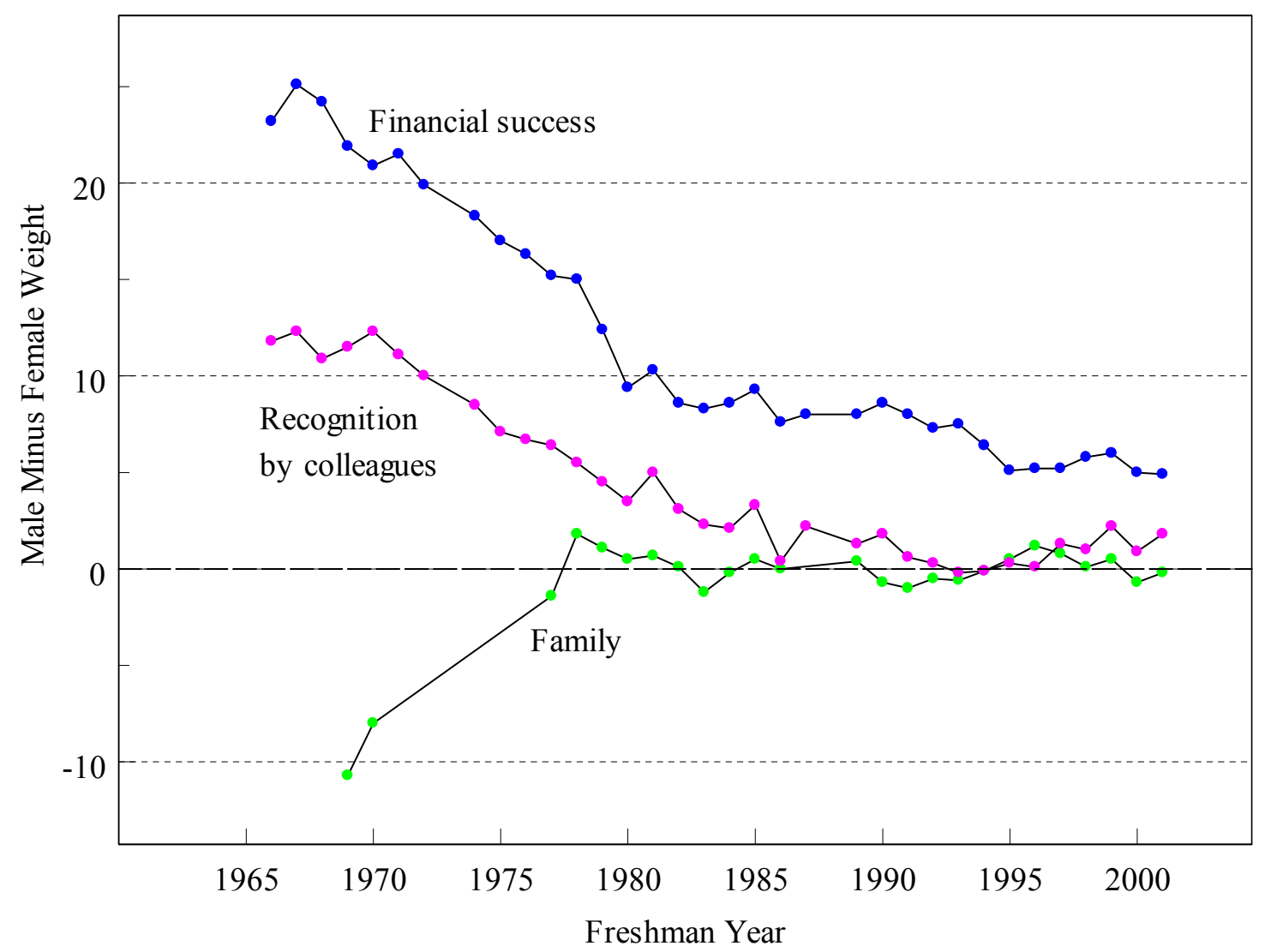

Source: Astin, et al. (2002).

Notes: Individuals surveyed were freshmen. The data given are weighted to produce a nationally representative college freshmen average. An objective, goal, or value is given full weight (100) if the individual listed it as "essential" or "very important" and no weight $(0)$ otherwise. Individuals could choose any number of factors from the 12 to 19 possible objectives, goals, or values listed on the survey in each year. 
Figure 7

Woman's Earnings as a Percentage of Men's Earnings: 1960 to 2003

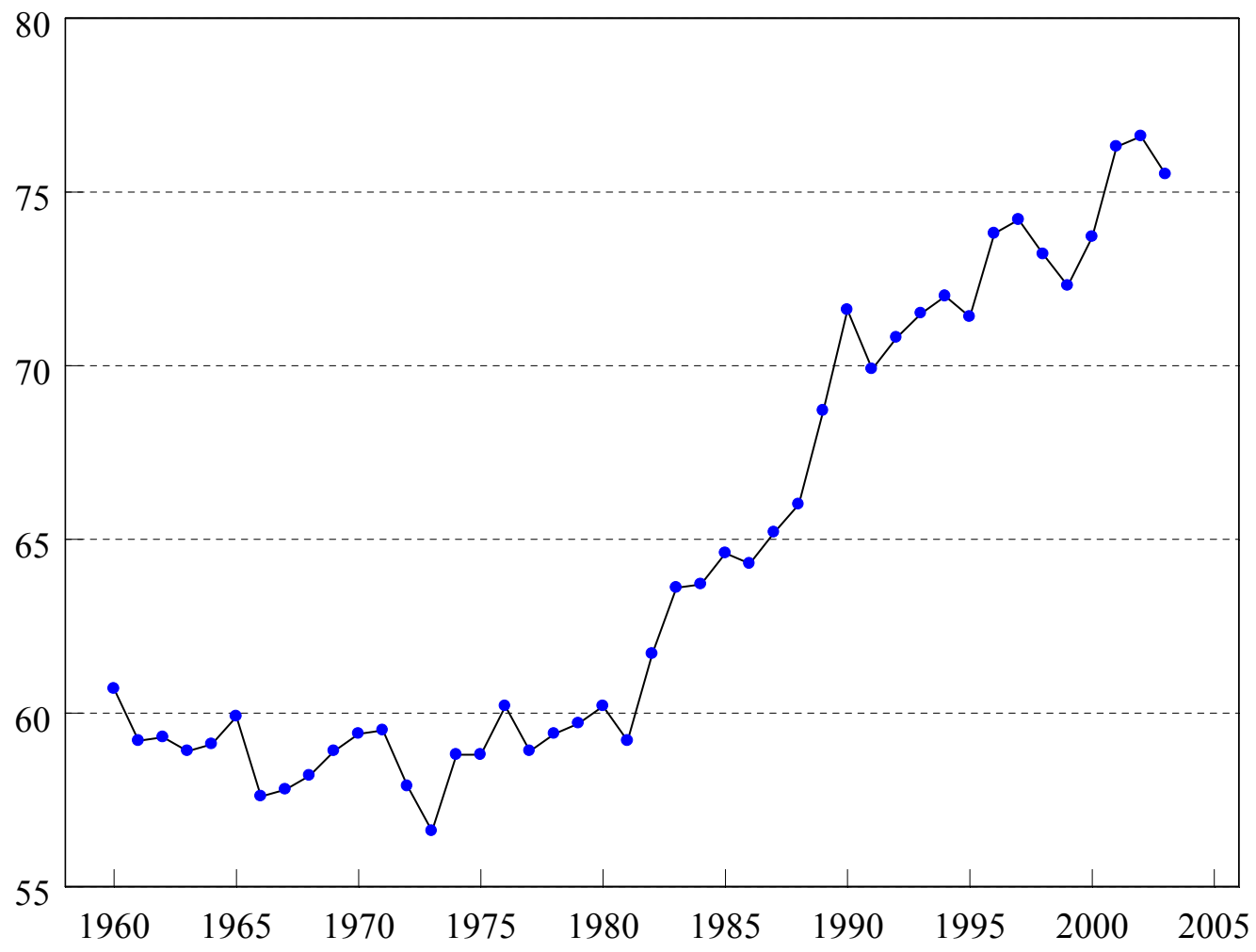

Sources: http://www.census.gov/hhes/income/histinc/p40.html

Notes: Based on median earnings of full-time, year-round workers fifteen years old and over as of March of the following year. Before 1989 earnings are for civilian workers only. 
Figure 8

Occupations of College Graduate Women, 30 to 34 Years Old: 1940 to 2000

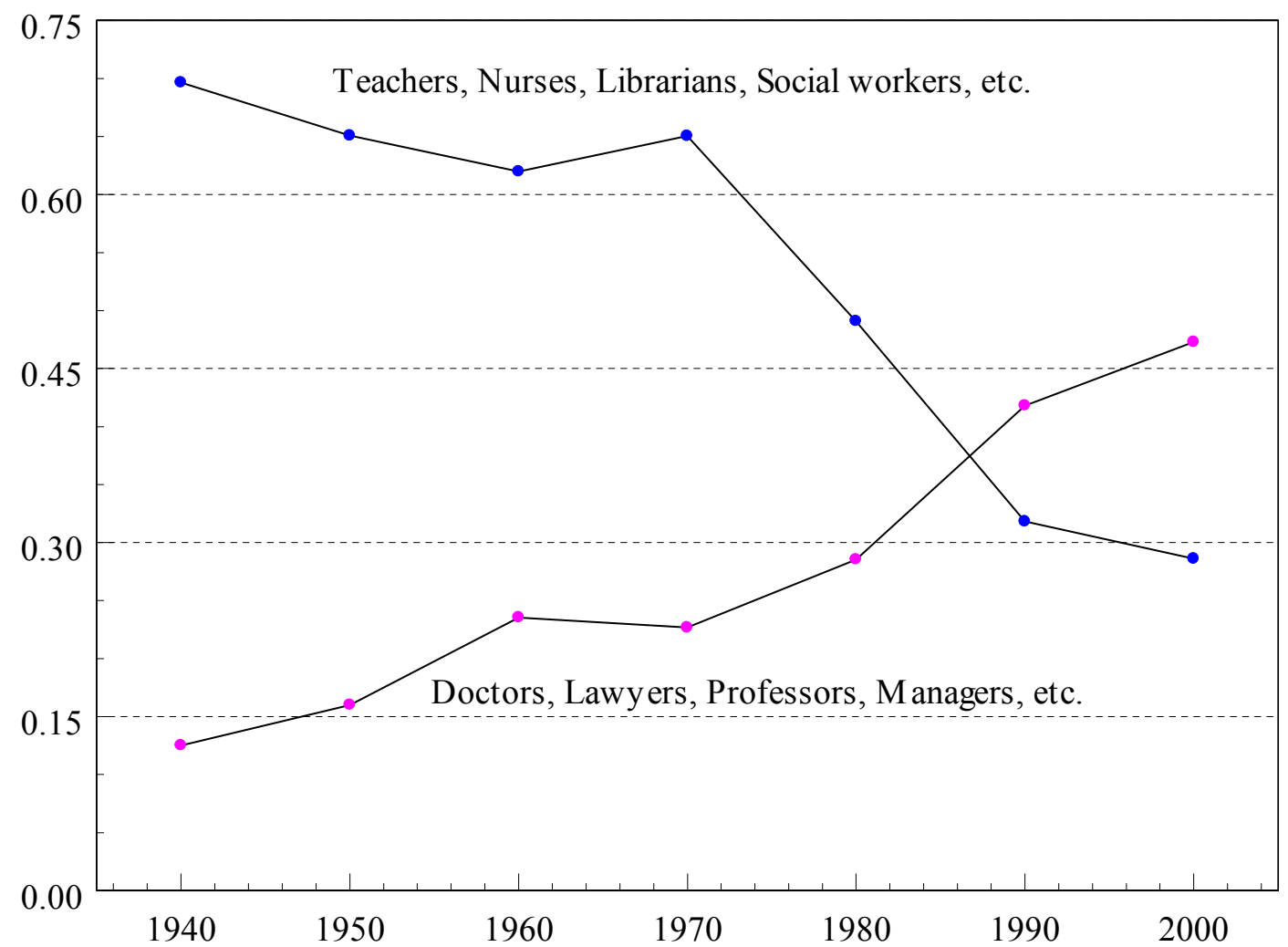

Sources: Integrated Public Use Micro-data Sample of the U.S. Federal Population Census, 1940 to 1960; March Current Population Survey 1970 to 2000.

Notes: The occupations in the two groups are: (1) grade school teachers, nurses, librarians, social or religious workers, and secretaries and other clerical workers; and (2) doctors, lawyers, professors, managers, and scientists. 
Figure 9

Fraction of Years Spent Married for All Women

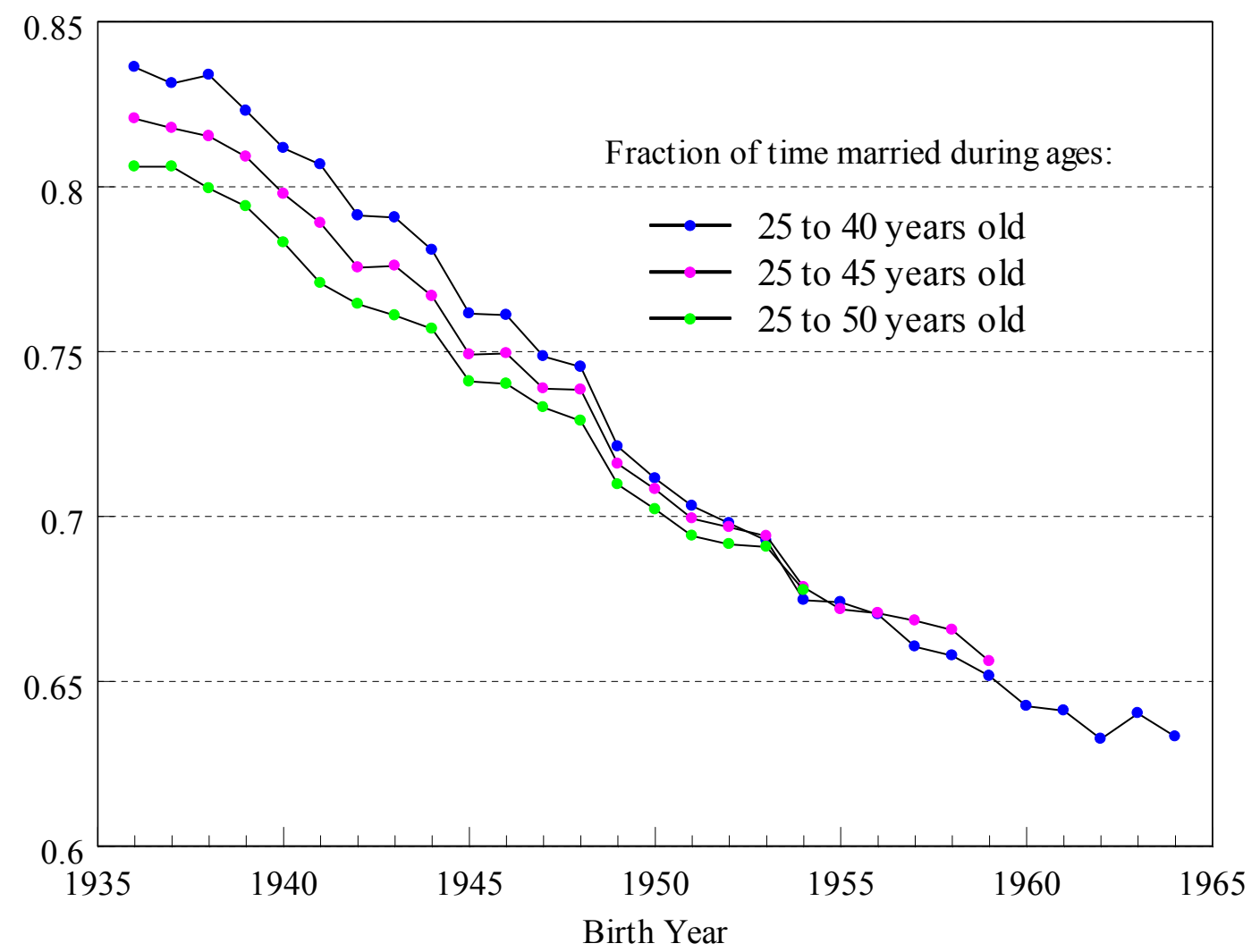

Source: March Current Population Survey (CPS), 1962 to 2004.

Notes: All education groups and all races are included. "Married" includes all who were listed as married, independent of whether the spouse was present. The data begin with age 25 years and end with age 50 years. A missing cell (25 year olds in 1961) was created by extrapolation. 
Figure 10

Labor Force Participation and Fraction with Young Children for 33 to 37 Year Old Married, College Graduate Women: 1962 to 2004

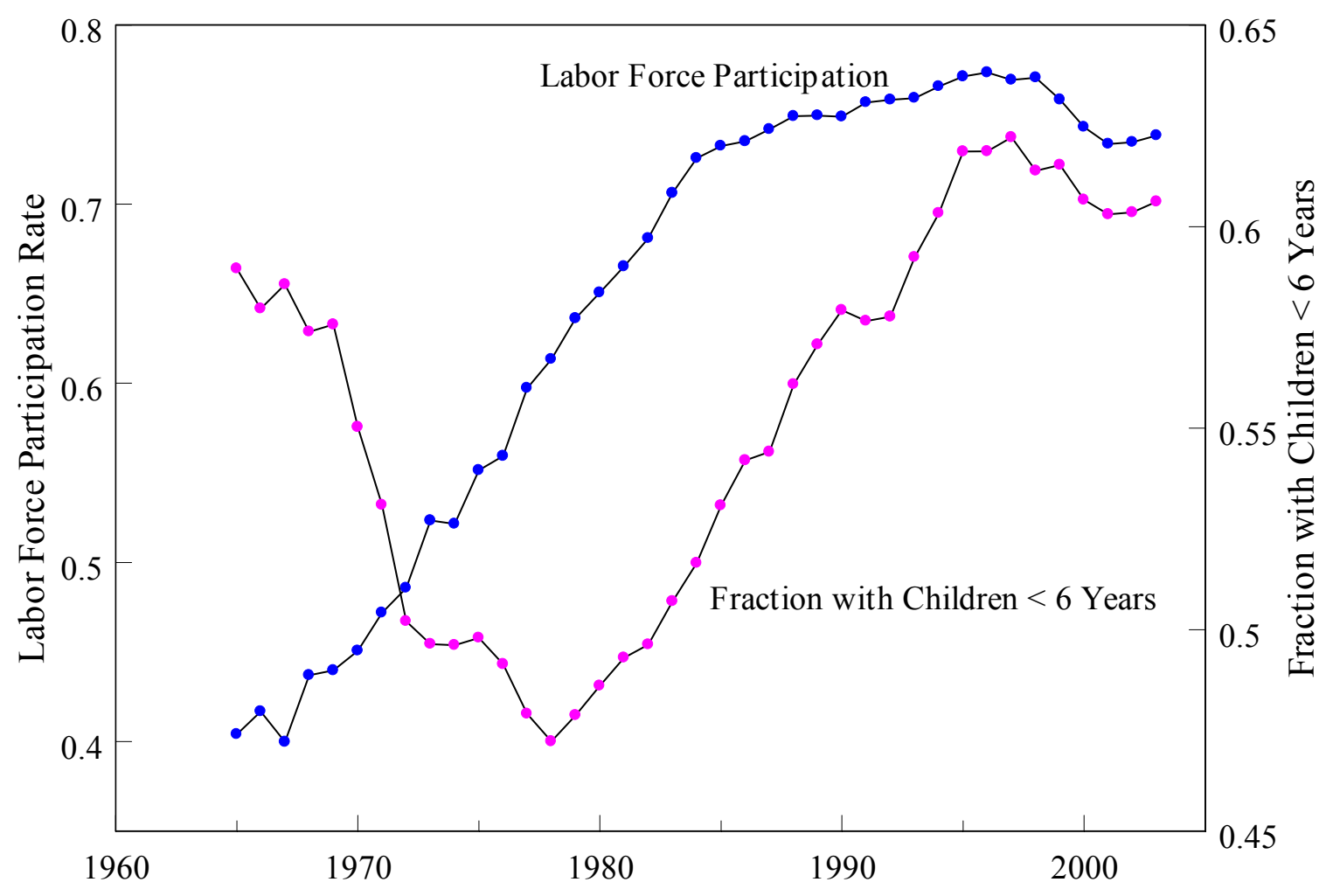

Source: March Current Population Survey CPS), 1962 to 2004.

Notes: Three-year centered moving averages are shown. "Married" means currently married although not necessarily with a spouse present. "College graduate" means greater than or equal to four years of college. 
Table 1

Total Out-of-Work Spells among Graduates of Selective Colleges and Universities:

Entering Class of 1976

\begin{tabular}{cccccc}
\hline \hline & \multicolumn{3}{c}{ Women } & & Men \\
\cline { 2 - 4 } \cline { 5 - 6 } $\begin{array}{c}\text { Total out-of-work spells } \\
\text { (excluding for education) }\end{array}$ & All & $\begin{array}{c}\text { With } \\
\text { children }\end{array}$ & $\begin{array}{c}\text { Without } \\
\text { children }\end{array}$ & $\begin{array}{c}\text { Prof. or grad. } \\
\text { degree }\end{array}$ & All \\
\hline 0 & 0.585 & 0.501 & 0.765 & 0.705 & 0.859 \\
0.5 years & 0.0351 & 0.0366 & 0.0315 & 0.0340 & 0.0222 \\
$>0.5$ to 1 years & 0.0745 & 0.0703 & 0.0837 & 0.0738 & 0.0513 \\
$>$ 1 to 2 years & 0.0713 & 0.0751 & 0.0629 & 0.0557 & 0.0360 \\
$>$ 2 to 5 years & 0.109 & 0.139 & 0.0446 & 0.0759 & 0.0228 \\
$>$ 5 to 15.5 years & 0.125 & 0.178 & 0.0125 & 0.0557 & 0.0084 \\
Mean years not working & 1.55 & 2.08 & 0.410 & 0.808 & 0.244 \\
Number of observations & 10,663 & 7,241 & 3,308 & 2,440 & 10,890 \\
\hline \hline
\end{tabular}

Source: Andrew W. Mellon Foundation, College and Beyond data set, entering class of 1976.

Notes: Sample includes only those who received a bachelor's degree from 1978 to 1985 . Of those women with a graduation date listed in the survey 98 percent received their degrees between 1978 and 1985 and 94 percent did between 1979 and 1981. Out-of-work spells are defined in the survey as those greater than 6 months each. The possible reasons for no work include: family responsibilities, layoffs, retirement, could not find a suitable position, did not want to work, and personal illness. Spells that were solely for educational reasons are excluded here. Professional or graduate degrees include doctorates (e.g., Ph.D.), professional degrees (e.g., M.D., D.S.S., D.V.M.), and law degrees but not master's degrees (e.g., M.A., M.B.A.). "Children" is the number listed by the respondent and may include adopted or stepchildren (or be missing). 


\section{References}

Abbott, Edith. "A History of Industrial Employment of Women in the United States: An Introductory Study.” Journal of Political Economy, October 1906, 14(8), pp. 461-501.

Acemoglu, Daron, David H. Autor, and David Lyle. "Women, War, and Wages: The Effect of Female Labor Supply on the Wage Structure at Mid-Century." Journal of Political Economy, June 2004, 112(3), pp. 497-551.

Akerlof, George A., and Rachel E. Kranton. "Economics and Identity." Quarterly Journal of Economics, August 2000, 115(3), pp. 715-52.

Astin, Alexander W., Leticia Oseguera, Linda J. Sex, and William S. Korn. The American freshman: Thirty-five year trends, 1966-2001. Los Angeles CA: Higher Education Research Institute, UCLA, 2002.

Babcock, Linda and Sara Laschever. Women don't ask: Negotiation and the gender divide. Princeton, NJ: Princeton University Press, 2004.

Becker, Gary S. A treatise on the family. Cambridge MA: Harvard University Press, 1981.

Belkin, Lisa. "The Opt-Out Revolution," The New York Times Magazine Section, October 26, 2003.

Blau, Francine D., and Lawrence M. Kahn. "Changes in the Labor Supply Behavior of Married Women: 1980-2000." National Bureau of Economic Research (Cambridge, MA) Working Paper No. 11230, 2005.

Blau, Francine D., and Lawrence M. Kahn. "Swimming Upstream: Trends in the Gender Wage Differential in the 1980s." Journal of Labor Economics, January 1997, 15(1), Part 1, pp. 142.

Boushey, Heather. "Are Women Opting Out? Debunking the Myth.” Center for Economic and Policy Research (Washington, D.C.) Briefing Paper, December 2005.

Bowen, William G., and Derek Bok. The shape of the river: The long term consequences of considering race in college and university admissions. Princeton, NJ: Princeton University Press, 1998.

Bowen, William G. and T. Aldrich Finegan. The economics of labor force participation. Princeton, NJ: Princeton University Press, 1969.

Cain, Glen G. Married women in the labor force: An economic analysis. Chicago: University of Chicago Press, 1966. 
Campbell, Helen. Women wage-earners: Their past, their present, and their future. With an introduction by Richard T. Ely. Boston, MA: Roberts Brothers, 1893.

Costa, Dora, and Matthew Kahn. "Power Couples: Changes in the Locational Choice of the College Educated, 1940-1990.” Quarterly Journal of Economics, November 2000, 115(4), pp. 1287-315.

Current Population Surveys, March 1962-2004 (machine-readable data files). Survey conducted by the Bureau of the Census for the Bureau of Labor Statistics. Washington, DC: Bureau of the Census (producer and distributor), 1962-2004. [CPS utilities. Santa Monica, CA: Unicon Research Corporation (producer and distributor), 2004].

De Long, J. Bradford, Claudia Goldin, and Lawrence F. Katz. "Sustaining U.S. Economic Growth," in Henry J. Aaron, James M. Lindsay, and Pietro S. Nivola, eds., Agenda for the nation. Washington, D.C.: Brookings Institution Press, 2003, pp. 17-60.

Douglas, Paul H. The theory of wages. New York: The MacMillan Company, 1934.

Douglas, Paul and Erika H. Schoenberg. "Studies in the Supply Curve of Labor: The Relation in 1929 between Average Earnings in American Cities and the Proportions Seeking Employment." Journal of Political Economy, February 1937, 45(1), pp. 45-79.

Durand, John D. The labor force in the United States: 1890-1960. New York: The Social Science Research Council, 1948.

Ehrenberg, Ronald G., and Robert S. Smith. Modern labor economics: Theory and public policy, Ninth Edition. Boston, MA: Pearson Addison Wesley Press, 2006.

Fernández, Raquel, Alessandra Fogli, and Claudia Olivetti. "Mothers and Sons: Preference Development and Female Labor Force Dynamics." Quarterly Journal of Economics, November 2004, 119(4), pp. 1249-299.

Goldin, Claudia. "From the Valley to the Summit: A Brief History of the Quiet Revolution that Transformed Women's Work.” Regional Review, Q1 2005, 14(3), pp. 5-12.

Goldin, Claudia. "Labor Markets in the Twentieth Century," in Stanley L. Engerman and Robert E. Gallman, eds., The Cambridge economic history of the United States, Vol. 3. New York: Cambridge University Press, 2000, pp. 549-624.

Goldin, Claudia. "America's Graduation from High School: The Evolution and Spread of Secondary Schooling in the Twentieth Century." Journal of Economic History, June 1998, 58(2), pp. 345-74.

Goldin, Claudia. "The U-Shaped Female Labor Force Function in Economic Development and Economic History," in T. Paul Schultz, ed., Investment in women's human capital and economic development. Chicago, IL: University of Chicago Press, 1995, pp. 61-90. 
Goldin, Claudia. "The Role of World War II in the Rise of Women's Work." American Economic Review, September 1991a, 81(4), pp. 741-56.

Goldin, Claudia. "Marriage Bars: Discrimination against Married Women Workers from the 1920s to the 1950s," in Henry Rosovsky, David Landes, and Patrice Higonnet, eds., Favorites of fortune: Technology, growth, and economic development since the industrial revolution. Cambridge, MA: Harvard University Press, 1991b, pp. 511-36.

Goldin, Claudia. Understanding the gender gap: An economic history of American women. New York: Oxford University Press, 1990.

Goldin, Claudia. "The Historical Evolution of Female Earnings Functions and Occupations," Explorations in Economic History, January 1984, 21(1), pp. 1-27.

Goldin, Claudia, and Lawrence F. Katz. "The Power of the Pill: Oral Contraceptives and Women's Career and Marriage Decisions." Journal of Political Economy, August 2002, 110(4), pp. 730-70.

Goldin, Claudia, Lawrence F. Katz, and Ilyana Kuziemko. "The Homecoming of American Women: The Reversal of the College Gender Gap.” Mimeo, Harvard University, October 2005.

Goldin, Claudia, Lawrence F. Katz, Qingyan Shang, and Bruce Weinberg. "Who’s Opting Out? Evidence from the CPS and Vital Statistics." In progress.

Goldin, Claudia, and Maria Shim. "Making a Name: Surnames of College Women at Marriage and Beyond." Journal of Economic Perspectives, Spring 2004, 18(2), pp. 143-60.

Greenwood, Jeremy, Ananth Seshadri, and Mehmet Yorukoglu. "Engines of Liberation.” Review of Economic Studies, January 2005, 72(1), pp. 109-33.

Hill, Caroline. "The Economic Value of the Home.” Journal of Political Economy, June 1904, 12(3), pp. 408-19.

Long, Clarence. The labor force under changing income and employment. Princeton, NJ: Princeton University Press for the NBER, 1958.

Lundberg, Shelly, and Robert A. Pollak. "Separate Spheres Bargaining and the Marriage Market.” Journal of Political Economy, December 1993, 101(6), pp. 988-1010.

McElroy, Marjorie B., and Mary Jean Horney. "Nash Bargained Household Decisions: Toward a Generalization of the Theory of Demand.” International Economic Review, June 1981, 22(2), pp. 333-49. 
Mincer, Jacob. "Labor Force Participation of Married Women: A Study of Labor Supply," in H. Gregg Lewis, ed., Aspects of labor economics. Universities-National Bureau Committee for Economic Research. Princeton, NJ: Princeton University Press, 1962, pp. 63-97.

Mincer, Jacob, and Solomon Polachek. "Family Investments in Human Capital: Earnings of Women." Journal of Political Economy, March-April 1974, 82(2), Part 2: Marriage, Family Human Capital, and Fertility, pp. S76-S108

Moehling, Caroline M. “Women's Work and Men's Unemployment.” Journal of Economic History, December 2001, 61(4), pp. 926-49.

Olivetti, Claudia. "Changes in Women's Hours of Market Work: The Role of Returns to Experience." Mimeo, Boston University, September 2005.

Olivetti, Claudia. "Measuring Changes in Returns to Experience: Learning-by-Doing and Gender Differentials." Mimeo, University of Pennsylvania, August 2001.

O’Neill, June, and Solomon Polachek. "Why the Gender Gap in Wages Narrowed in the 1980s." Journal of Labor Economics, January 1993, 11(1), Part 1: Essays in Honor of Jacob Mincer, pp. 205-28.

Rosen, Ruth. The world split open: How the modern women's movement changed America. New York: Viking, 2000.

Rubin, Lillian. Families on the fault line. New York: Harper Collins 1994.

U.S. Department of Education, NCES. Digest of Education Statistics 2004. Washington, D.C., G.P.O., 2005. Available on-line only: http://nces.ed.gov/programs/digest/d04/index.asp

Wolfers, Justin. "Did Unilateral Divorce Laws Raise Divorce Rates? A Reconciliation and New Results. National Bureau of Economic Research (Cambridge, MA) Working Paper No. 10014, October 2003. 